\title{
Emergence of homochiral benzene-1,3,5-tricarboxamide helical assemblies and catalysts upon addition of an achiral monomer
}

\author{
Yan Li, Ahmad Hammoud, Laurent Bouteiller and Matthieu Raynal*
}

Supporting Information

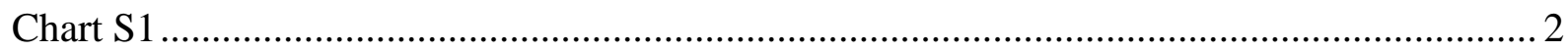

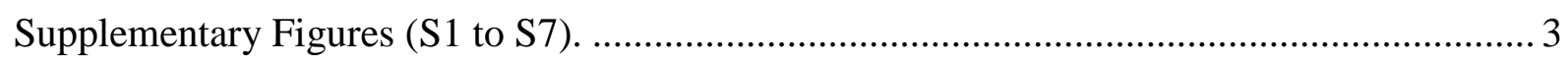

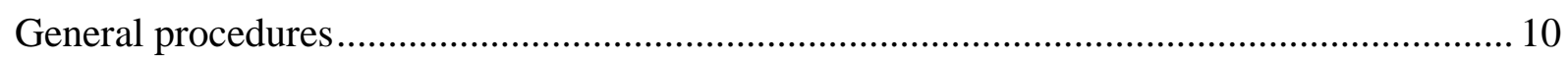

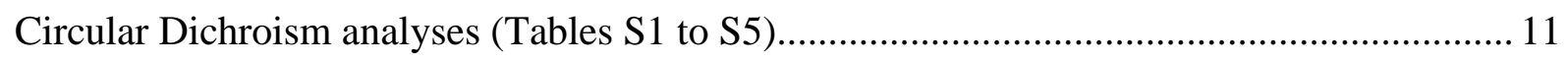

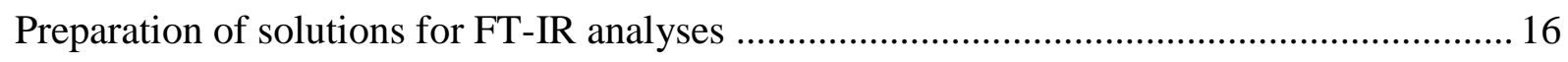

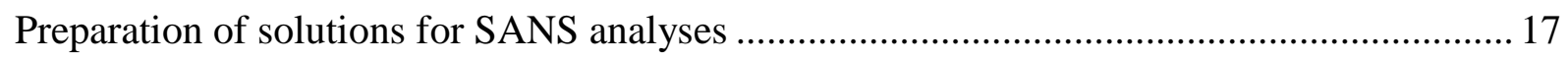

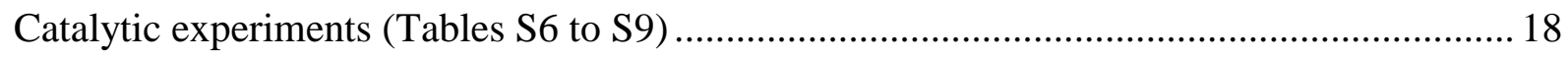

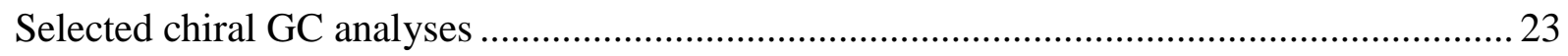

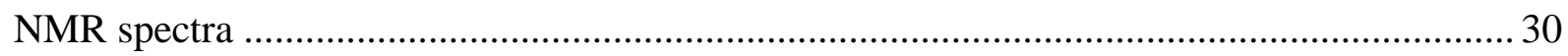

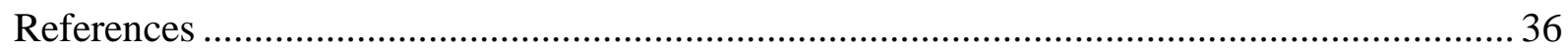



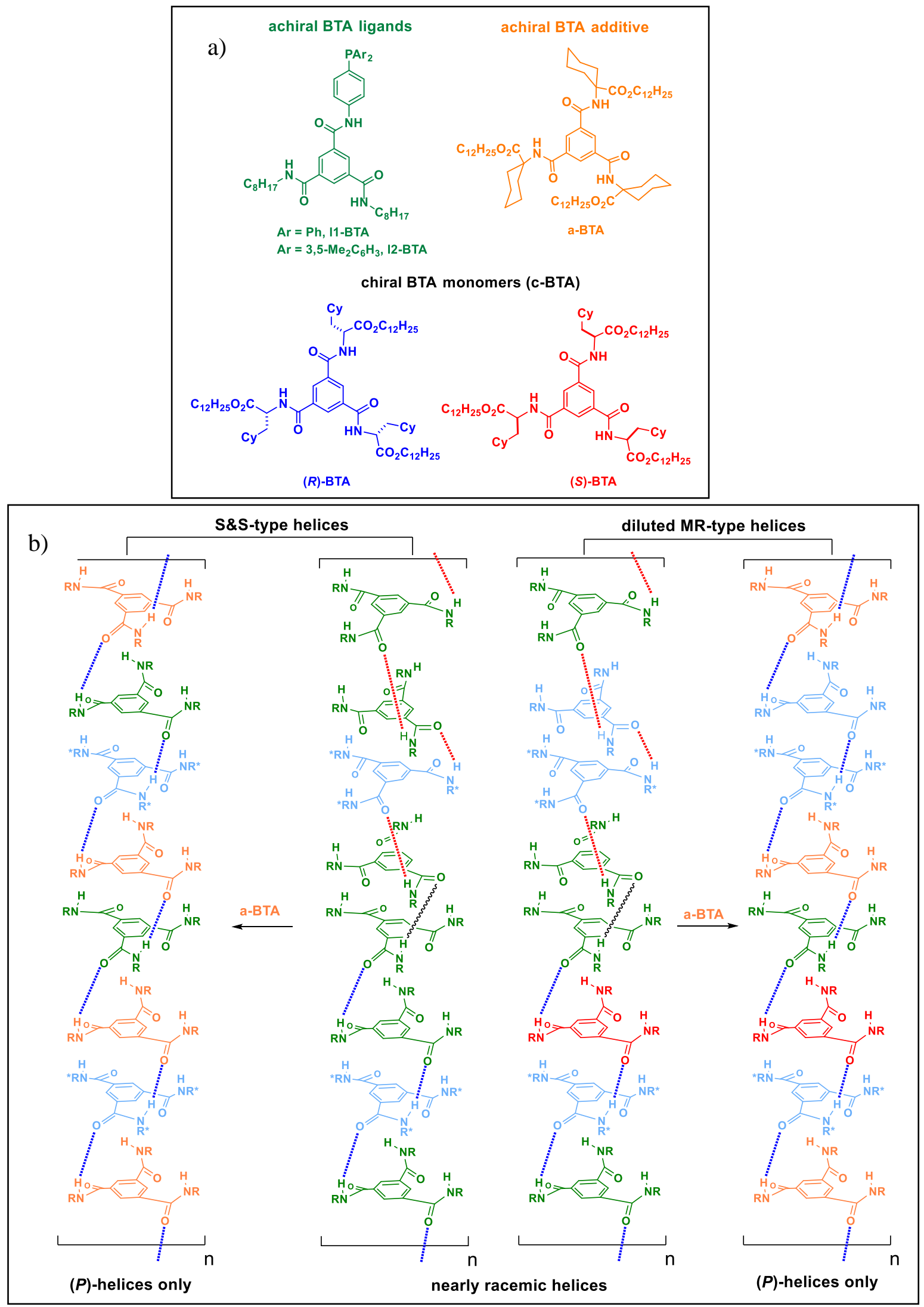

Chart S1 a) Chemical structures of the BTA molecules investigated in this study. b) Tentative molecular representation of the concept shown in Scheme 1 with BTA co-assemblies. The dark wavy bond represents a helix reversal (for clarity, a single array of hydrogen bonds is shown). 


\section{Supplementary Figures (S1 to S7).}

\section{I1-BTA + [Cu] + (S)-BTA}

a)

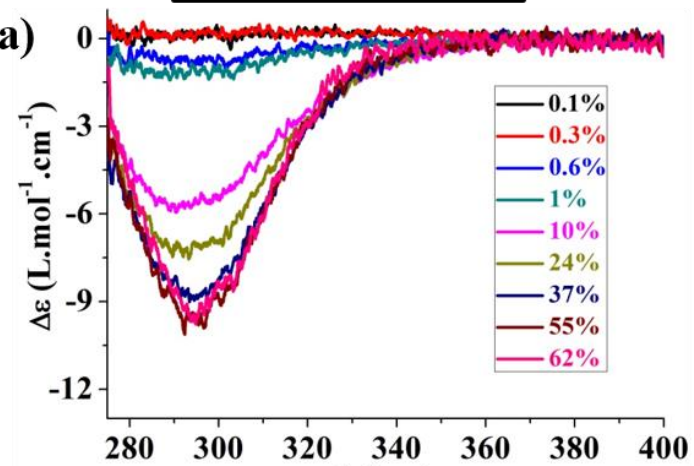

c)
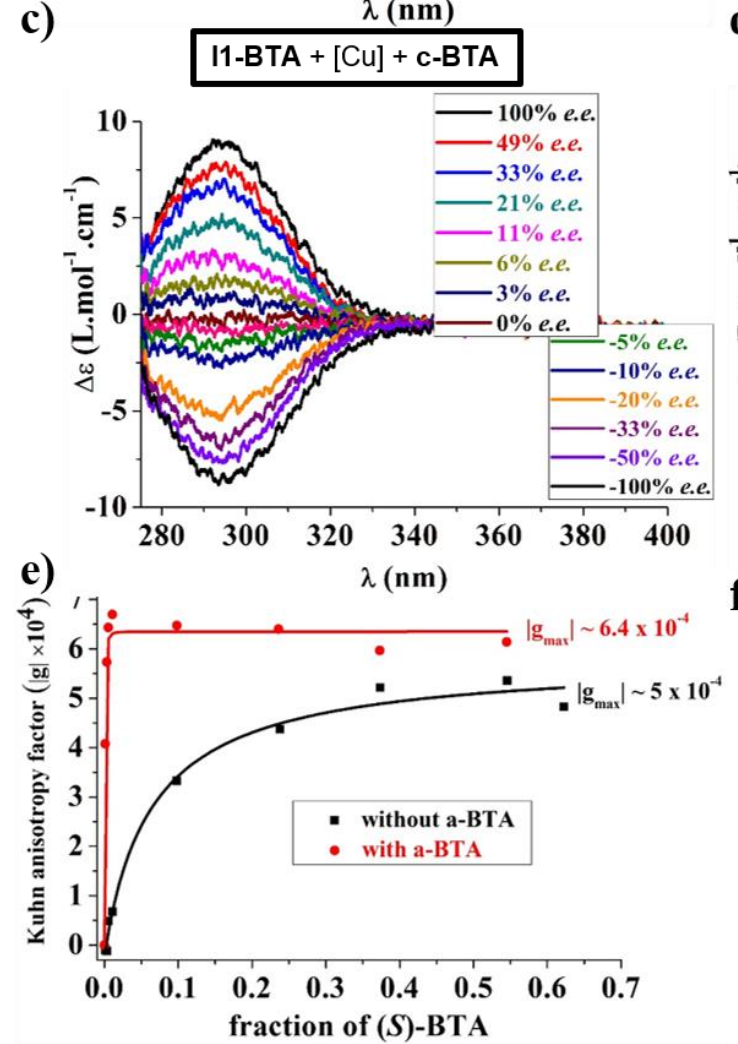

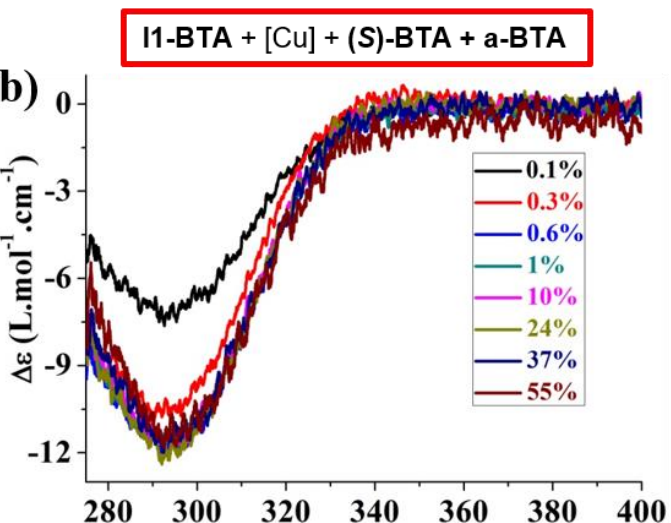

d)
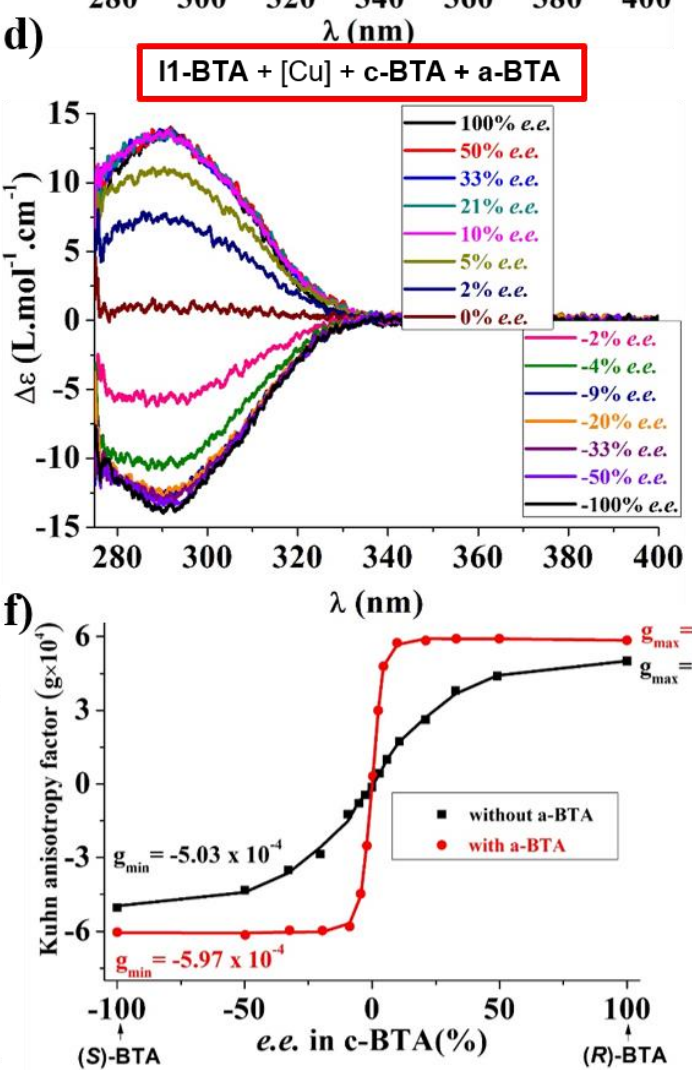

Figure S1 Effect of the achiral BTA additive on S\&S and diluted MR effects performed at a total concentration in BTA monomers $([\mathbf{1 1 - B T A}]+[\mathbf{a}-\mathbf{B T A}]+[\mathbf{c - B T A}]=5.8 \pm 0.4 \mathrm{mM})$.

a) $\mathrm{CD}$ analyses of the $\mathrm{S \& S}$-type mixtures without a-BTA $\left([\mathbf{1 1 - B T A}] /\left[\mathrm{Cu}(\mathrm{OAc})_{2} \cdot \mathrm{H}_{2} \mathrm{O}\right]=4,2.33 \leq[\mathbf{1 1 - B T A}] \leq 5.82\right.$ $\mathrm{mM}, 0.007 \leq[(\boldsymbol{S})$-BTA $] \leq 3.84 \mathrm{mM})$.

b) $\mathrm{CD}$ analyses of the $\mathrm{S} \& \mathrm{~S}$-type mixtures with a-BTA $\left([11-\mathbf{B T A}] /\left[\mathrm{Cu}(\mathrm{OAc})_{2} \cdot \mathrm{H}_{2} \mathrm{O}\right]=4,[\mathbf{1 1 - B T A}] /[\mathbf{a}-\mathbf{B T A}]=1\right.$, $1.36 \leq[\mathbf{1 1 - B T A}] \leq 2.90 \mathrm{mM}, 0.006 \leq[(\boldsymbol{S})$-BTA $] \leq 3.26 \mathrm{mM})$.

c) $\mathrm{CD}$ analyses of the diluted majority-rules type mixtures without a-BTA $\left([\mathbf{1 1 - B T A}] /\left[\mathrm{Cu}(\mathrm{OAc})_{2} \cdot \mathrm{H}_{2} \mathrm{O}\right]=4\right.$, $[\mathbf{l 1}$ BTA $]=2.79 \pm 0.03 \mathrm{mM},-100 \%$ e.e. $\leq \mathbf{c}-\mathbf{B T A} . \leq 100 \%$ e.e., $\left.\mathrm{f}_{\mathrm{c}-\mathrm{BTA}}=0.52\right)$.

d) $\mathrm{CD}$ analyses of the diluted majority-rules type mixtures with a-BTA $\left([\mathbf{1 1 - B T A}] /\left[\mathrm{Cu}(\mathrm{OAc})_{2} \cdot \mathrm{H}_{2} \mathrm{O}\right]=4\right.$, $[\mathbf{1 1 -}$ BTA $]=[\mathbf{a}-\mathbf{B T A}]=1.39 \pm 0.03 \mathrm{mM},-100 \%$ e.e. $\leq \mathbf{c}-\mathbf{B T A} . \leq 100 \%$ e.e., $\left.\mathrm{f}_{\mathrm{c}-\mathrm{BTA}}=0.52\right)$.

e) Kuhn anisotropy factor (g) measured at $\lambda=295 \mathrm{~nm}$ as a function of the fraction of $(\boldsymbol{S})$-BTA in the mixtures. Lines are guides for the eye.

f) Kuhn anisotropy factor (g) measured at $\lambda=295 \mathrm{~nm}$ as a function of the optical purity in c-BTA in the mixtures. Lines are guides for the eye. 
Interpretation of Figure S1: In the presence of a-BTA, both S\&S and diluted MR effects are enhanced in the same proportion as observed for the experiments performed at constant concentration in [11-BTA] (Figures 1 and 2). However, the $\left|g_{\max }\right|$ values obtained in the $S \& S$ experiments without additive and in the diluted MR experiments both with and without additive are lower than the $\left|g_{\max }\right|$ values reached for the experiments performed at constant concentration in [11-BTA]. The fact that a homochiral state is not reached under these conditions probably comes from the lower concentration in [11-BTA] since relatively short assemblies of the BTA ligand can be expected close to its critical concentration (measured at $\approx 0.5 \mathrm{mM}$ ). ${ }^{1}$

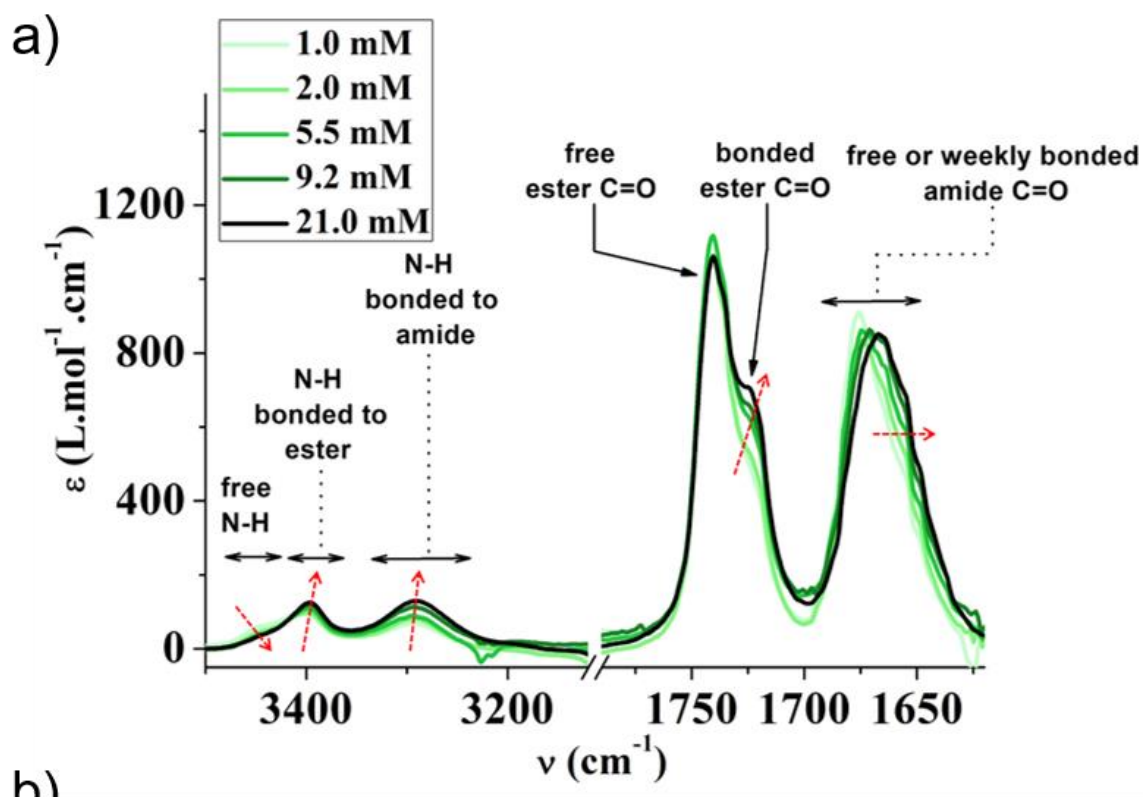

b)

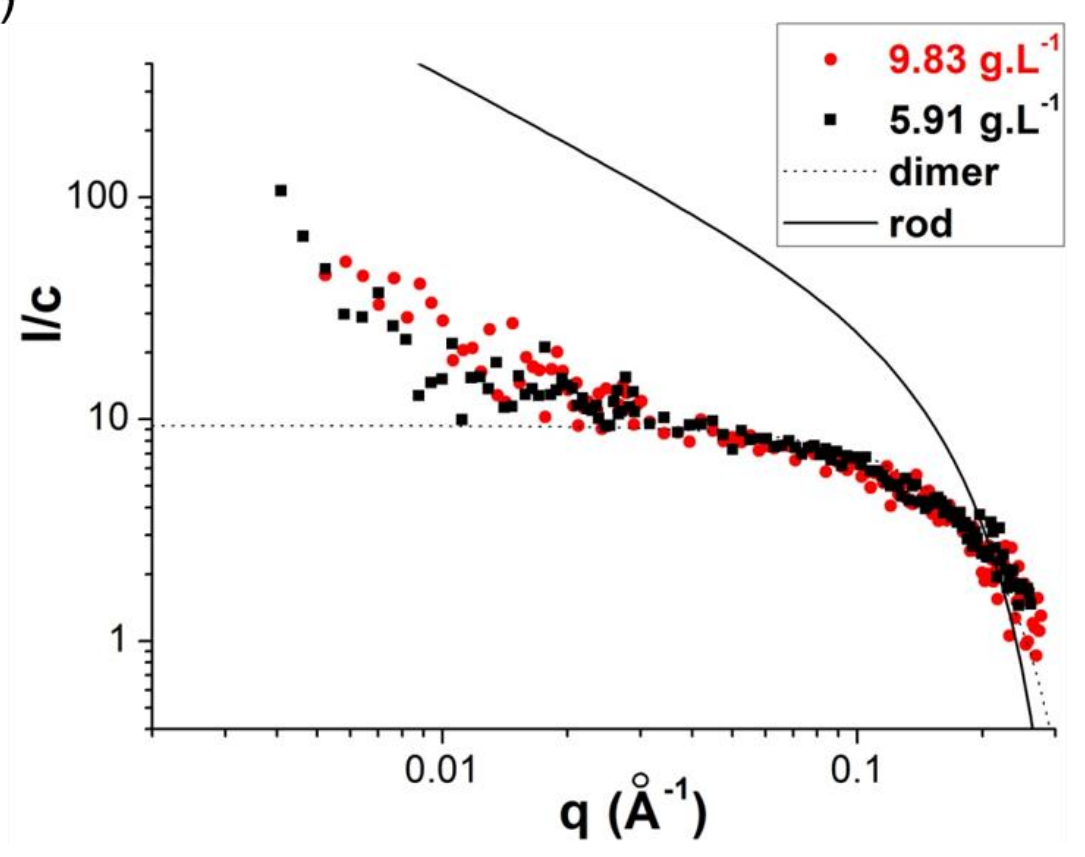

Figure S2 Characterization of the self-assemblies formed by a-BTA (293 K). a) FT-IR spectra at different concentrations in toluene (Inset: zoom on the $\mathrm{N}-\mathrm{H}$ region). $\varepsilon=\mathrm{Abs} /(\mathrm{l} \times \mathrm{c})$ where 1 and $\mathrm{c}$ are the cell path length in $\mathrm{cm}$ and the concentration in mol. $\mathrm{L}^{-1}$, respectively. Assignment of the $\mathrm{N}-\mathrm{H}$ and $\mathrm{C}=\mathrm{O}$ bands according to literature ${ }^{2}$ : free $\mathrm{N}-\mathrm{H}\left(3448 \mathrm{~cm}^{-1}\right), \mathrm{N}-\mathrm{H}$ bonded to ester $\mathrm{C}=\mathrm{O}\left(3402 \mathrm{~cm}^{-1}\right), \mathrm{N}-\mathrm{H}$ weakly bonded to amide $\mathrm{C}=\mathrm{O}$ $\left(3293 \mathrm{~cm}^{-1}\right)$, free ester $\mathrm{C}=\mathrm{O}\left(1740 \mathrm{~cm}^{-1}\right)$, bonded ester $\mathrm{C}=\mathrm{O}\left(1724 \mathrm{~cm}^{-1}\right)$, and free/weakly bonded amide $\mathrm{C}=\mathrm{O}$ $\left(1676 \mathrm{~cm}^{-1}\right.$, the fact that this band is broad means that there is a large distribution of carbonyl functions in the self-assemblies). b) SANS analyses at 5.91 g.L $\mathrm{L}^{-1}(5.42 \mathrm{mM})$ and $9.83 \mathrm{~g} . \mathrm{L}^{-1}(9.01 \mathrm{mM})$ in $\mathrm{C}_{7} \mathrm{D}_{8}$ together with the theoretical curves expected for a dimer (sphere of radius $12 \AA$ ) or for a rod (infinitely long cylinder of radius $12 \AA)$. 


\section{a)}

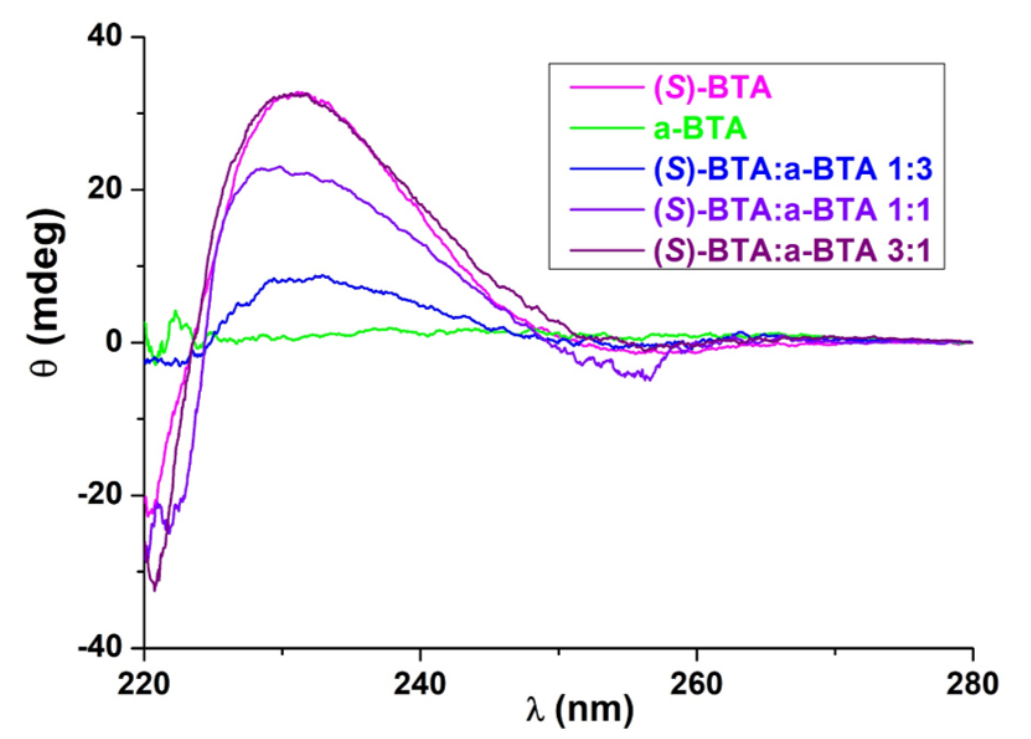

b)

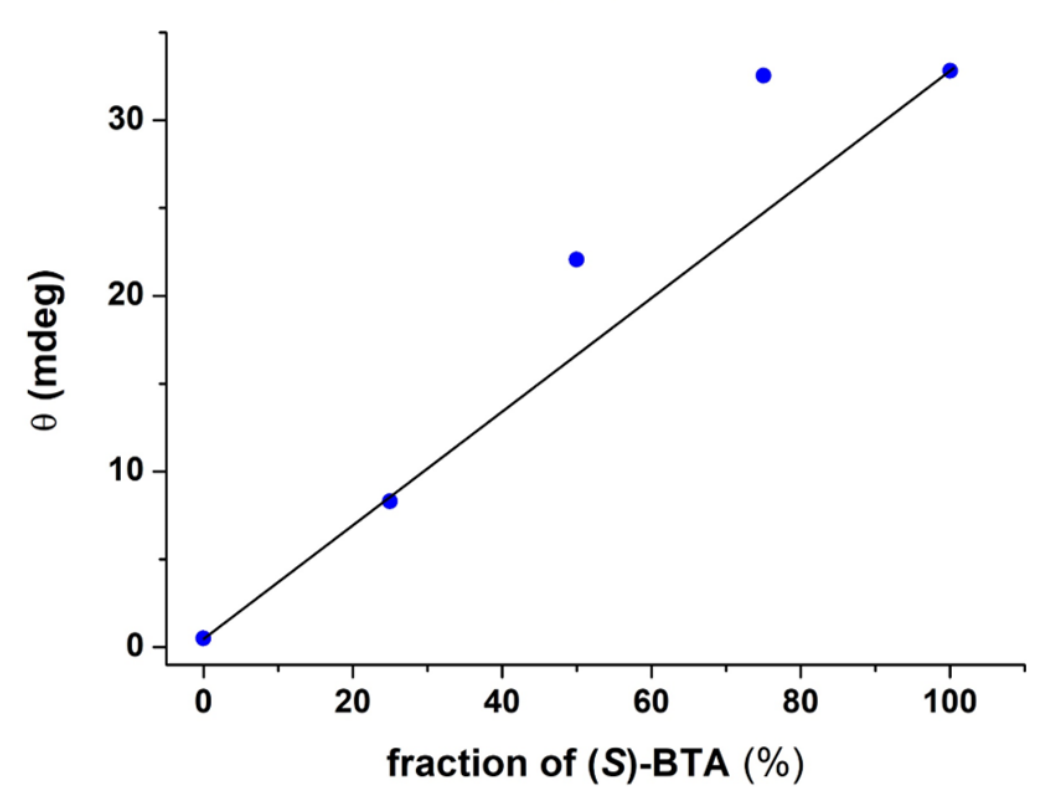

Figure S3 Characterization of the mixtures between $(S)$-BTA and a-BTA by CD spectroscopy. a) CD spectra of $(\boldsymbol{S})$-BTA $(14 \mathrm{mM})$, a-BTA $(14 \mathrm{mM})$ and their $1: 3$ mixture $\{(\boldsymbol{S})$-BTA $(3.5 \mathrm{mM})+$ a-BTA $(10.5 \mathrm{mM})\}$, 1:1 mixture $\{(\boldsymbol{S})$-BTA $(7.0 \mathrm{mM})+$ a-BTA $(7.0 \mathrm{mM})\}$, and $3: 1$ mixture $\{(\boldsymbol{S})$-BTA $(10.5 \mathrm{mM})+$ a-BTA $(3.5$ $\mathrm{mM})\}$ in toluene $(293 \mathrm{~K})$. b) Plot of the CD intensity at $\lambda=231 \mathrm{~nm}$ as a function of the fraction of $(\boldsymbol{S})$-BTA in the binary mixtures. The black line shows the linear relationship between the CD intensity and the amount of $(S)$ BTA in the mixture as expected for a system lacking chirality amplification.

Interpretation: The shape of all CD spectra is fingerprint of the dimers formed by $(\boldsymbol{S})$-BTA. ${ }^{2 \mathrm{c}}$ The intensity of the CD signal at $\lambda=231 \mathrm{~nm}$ is also closely proportional to the fraction of $(\boldsymbol{S})$-BTA in the mixture (the deviation at high $(S)$-BTA fractions might be related to some co-aggregation or uncertainty in the CD measurements). Accordingly, these CD measurements are in agreement with the FT-IR analysis shown in Fig. $3 b$ confirming that (S)-BTA and a-BTA preferentially self-segregate. 


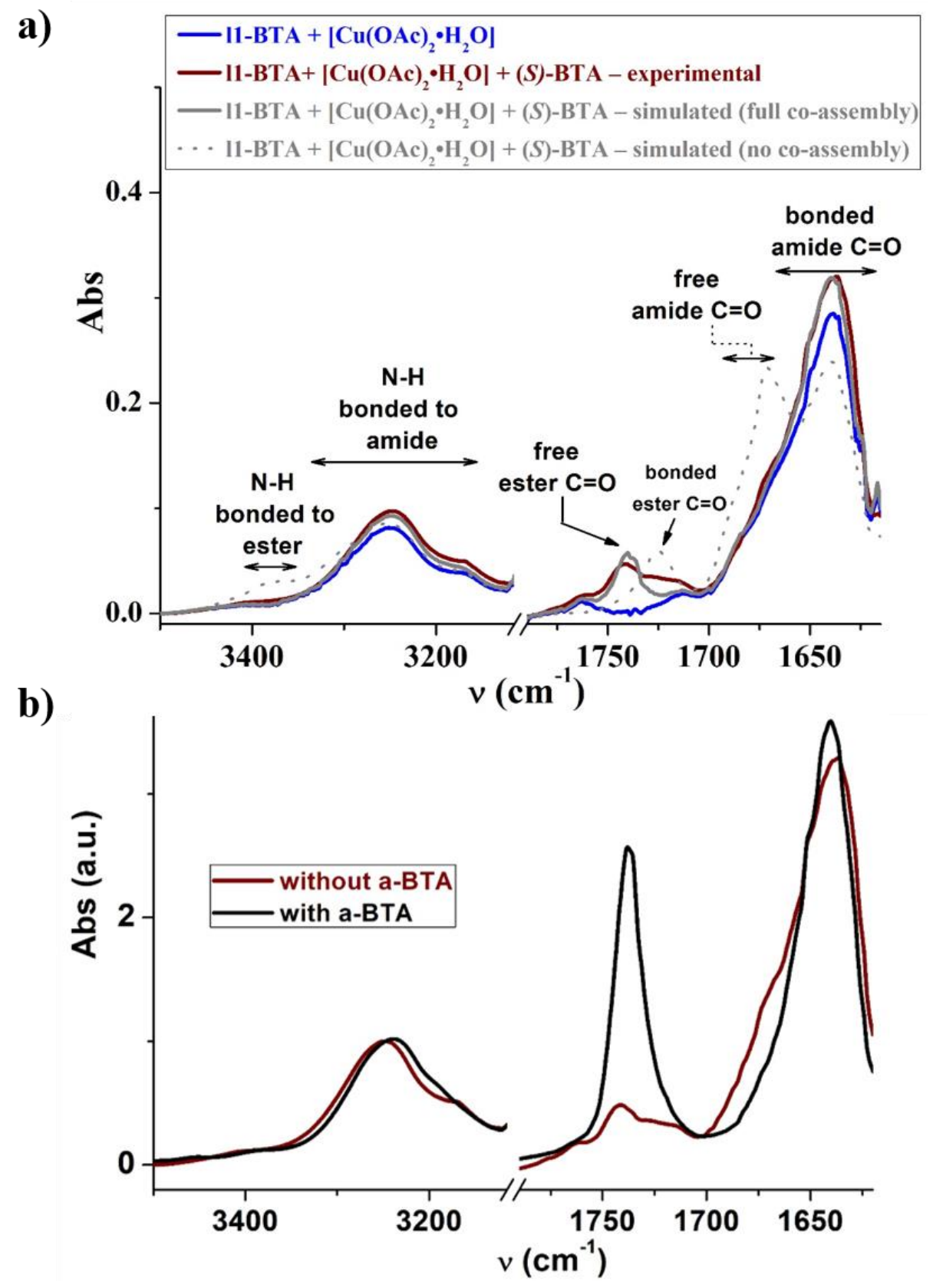

Figure S4 Probing the role of a-BTA in the co-assemblies (1). a) FT-IR spectra of the mixtures \{11-BTA (5.8 $\left.\mathrm{mM})+\left[\mathrm{Cu}(\mathrm{OAc})_{2} \cdot \mathrm{H}_{2} \mathrm{O}\right](1.45 \mathrm{mM})\right\}$ and $\left\{\mathbf{I 1 - B T A}(5.8 \mathrm{mM})+\left[\mathrm{Cu}(\mathrm{OAc})_{2} \cdot \mathrm{H}_{2} \mathrm{O}\right](1.45 \mathrm{mM})+(\boldsymbol{S})-\mathbf{B T A}(0.58\right.$ $\left.\left.\mathrm{mM}, \mathrm{f}_{\mathrm{Cha}}=0.09\right)\right\}$ in toluene. Simulated spectra for no and full co-assembly. The simulated spectrum for full coassembly was obtained by considering that all $(\boldsymbol{S})$-BTA monomers adopt the conformation of BTA Aib monomers in the co-assembled helical stacks (i.e. that they have the same IR spectrum). ${ }^{2 \mathrm{c}}$ The good agreement of this simulation with the experimental spectrum means that most of the BTA monomers stack into the helical co-assemblies (fraction $\geq 90 \%$ by considering the measurement uncertainty). Zoom on the $\mathrm{N}-\mathrm{H}$ and the $\mathrm{C}=\mathrm{O}$ regions. b) Overlap of the FT-IR spectra of the mixtures with and without a-BTA (see composition in the caption of Figures $3 b$ and S4a, respectively). The spectra have been normalized at the same absorbance value for $v=$ $3247 \mathrm{~cm}^{-1}$. The major difference is the higher intensity of the band at $\mathrm{v}=1738 \mathrm{~cm}^{-1}$ which is related to the free ester $\mathrm{C}=\mathrm{O}$ functions of a-BTA in the co-assemblies. Minor differences are: i) the shift of the maximum $\mathrm{N}-\mathrm{H}$ band from 3248 to $3239 \mathrm{~cm}^{-1}$ and ii) the narrowing of the amide I band in presence of a-BTA. Both observations support the formation of a stronger and more regular intermolecular hydrogen bond network in the presence of the achiral BTA additive. 
a)
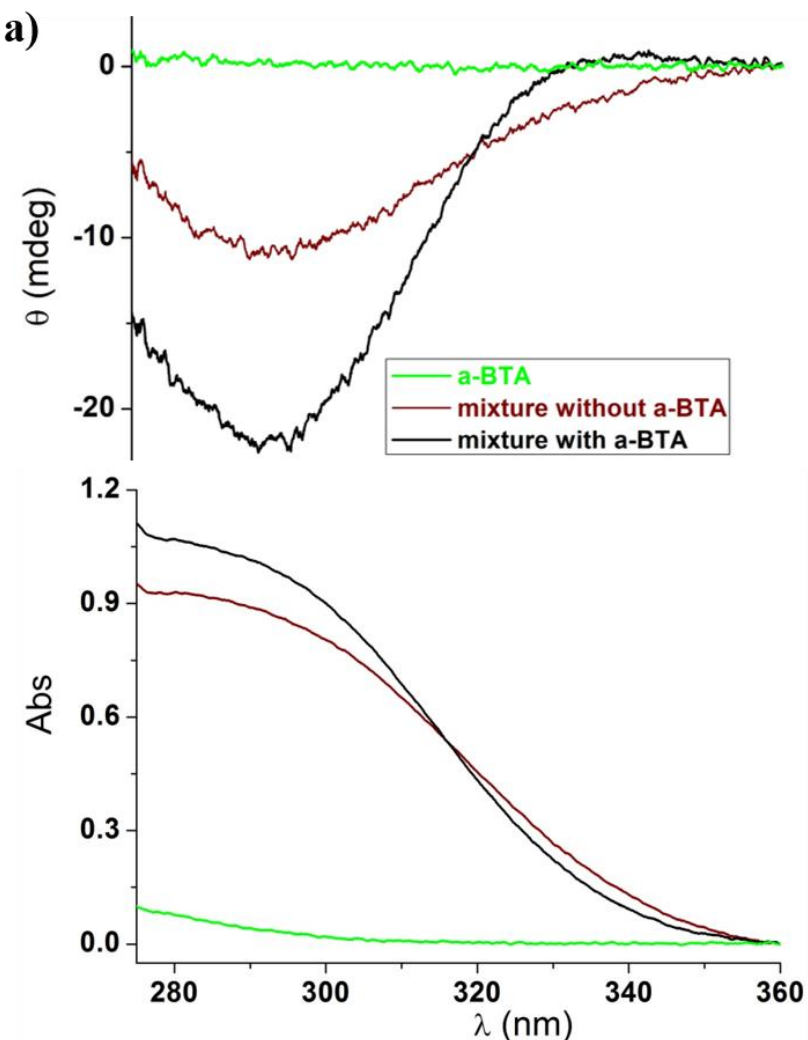

b)
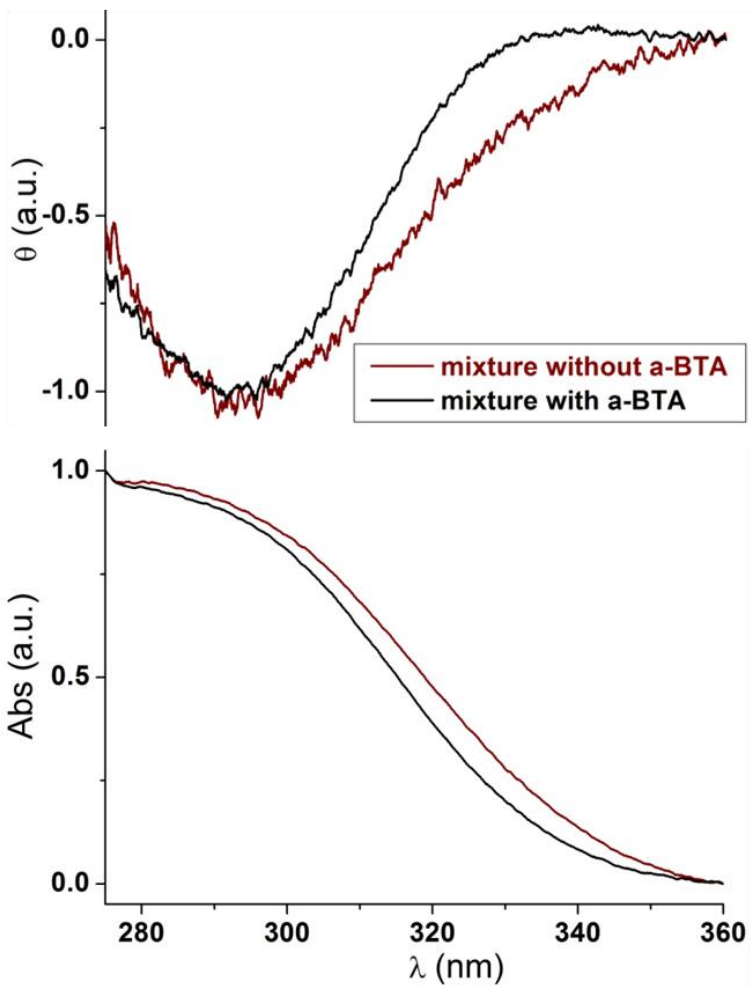

Figure S5 Probing the role of a-BTA in the co-assemblies (2). a) CD (top) and UV-Vis absorption analyses (bottom) of mixtures with and without a-BTA (see composition in the caption of Figures $3 \mathrm{~b}$ and S4a, respectively) and of a-BTA alone (5.8 $\mathrm{mM}$, toluene). b) Same data normalized at the maximum of the CD or UV-Vis main absorption band. 
a)

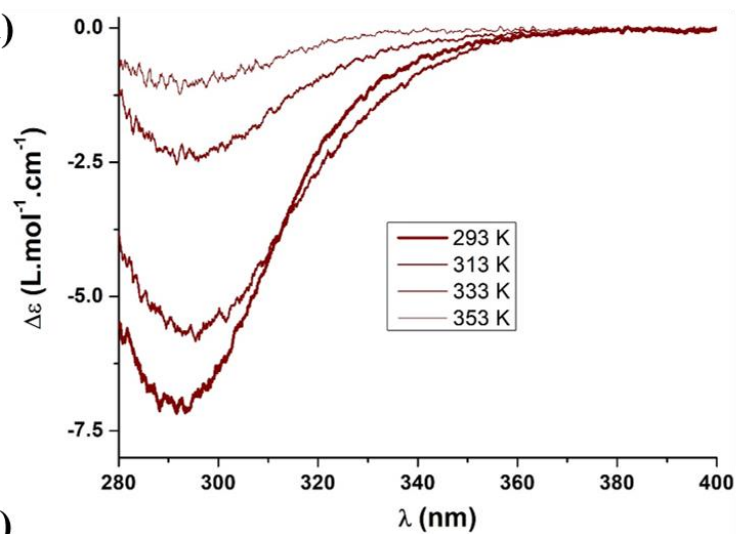

c)

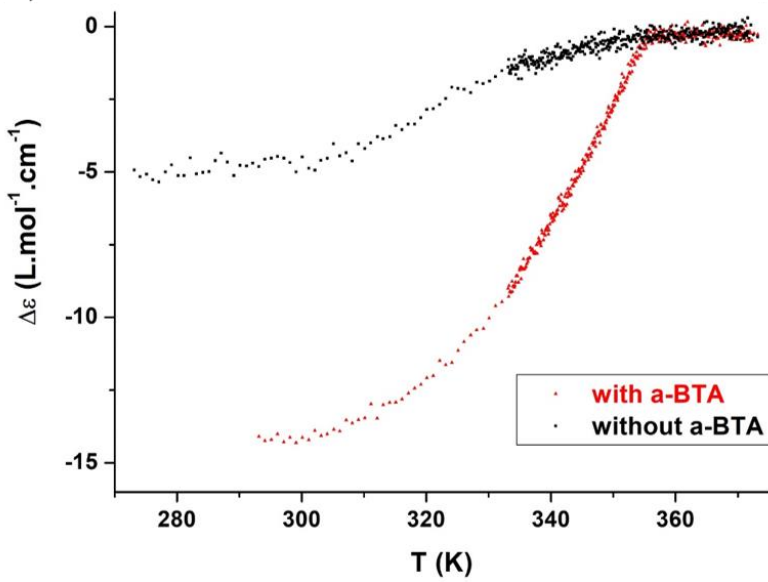

b)

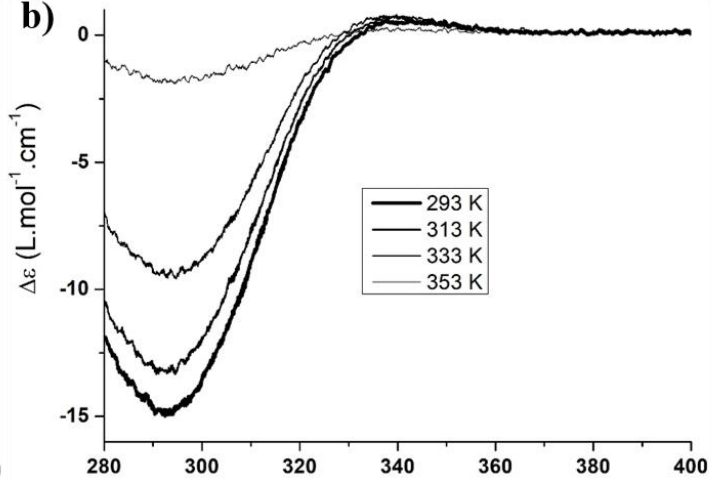

d)

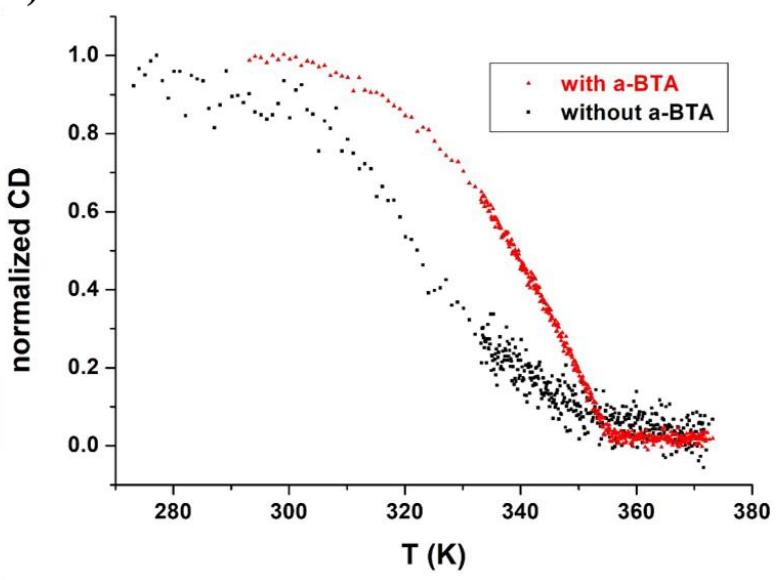

Figure S6 Probing the role of a-BTA in the co-assemblies (3). a) CD spectra at different temperatures of the mixture $\left\{\right.$ I1-BTA $(5.3 \mathrm{mM})+\left[\mathrm{Cu}(\mathrm{OAc})_{2} \cdot \mathrm{H}_{2} \mathrm{O}\right](1.33 \mathrm{mM})+(\boldsymbol{S})$-BTA $\left.\left(0.58 \mathrm{mM}, \mathrm{f}_{\mathrm{Cha}}=0.10\right)\right\}$ in toluene. b) $\mathrm{CD}$ spectra at different temperatures of the mixture $\left\{\right.$ I1-BTA $(2.65 \mathrm{mM})+\left[\mathrm{Cu}(\mathrm{OAc})_{2} \cdot \mathrm{H}_{2} \mathrm{O}\right](0.66 \mathrm{mM})+(\boldsymbol{S})$-BTA $\left.\left(0.58 \mathrm{mM}, \mathrm{f}_{\mathrm{Cha}}=0.10\right)+\mathbf{a}-\mathbf{B T A}(2.65 \mathrm{mM})\right\}$ in toluene. c) Comparison of the VT-CD analyses with and without a-BTA (cooling experiments, $\lambda=295 \mathrm{~nm}, 0.3 \mathrm{~K} \cdot \mathrm{min}^{-1}$, molar CD values). d) Comparison of the VT-CD analyses with and without a-BTA (cooling experiments, $\lambda=295 \mathrm{~nm}, 0.3 \mathrm{~K} \cdot \mathrm{min}^{-1}$, normalized CD values).

Interpretation: The influence of a-BTA on the disassembly/assembly process has been probed by $\mathrm{CD}$ spectroscopy for mixtures containing equal concentrations in BTA monomers $([\mathbf{l 1}-\mathbf{B T A}]+[(\boldsymbol{S})$-BTA $]+[\mathbf{a}-$ BTA $]=5.8 \mathrm{mM}$ ). Above $360 \mathrm{~K}$, the absence of $\mathrm{CD}$ signal infers that helices are disrupted for the two mixtures. Comparison of the VT-CD cooling curves clearly shows that helical assemblies with a-BTA are more stable (by ca. $20 \mathrm{~K}$ ) than those lacking a-BTA. The assembly process for the a-BTA containing helices is also substantially more cooperative. ${ }^{3}$ 


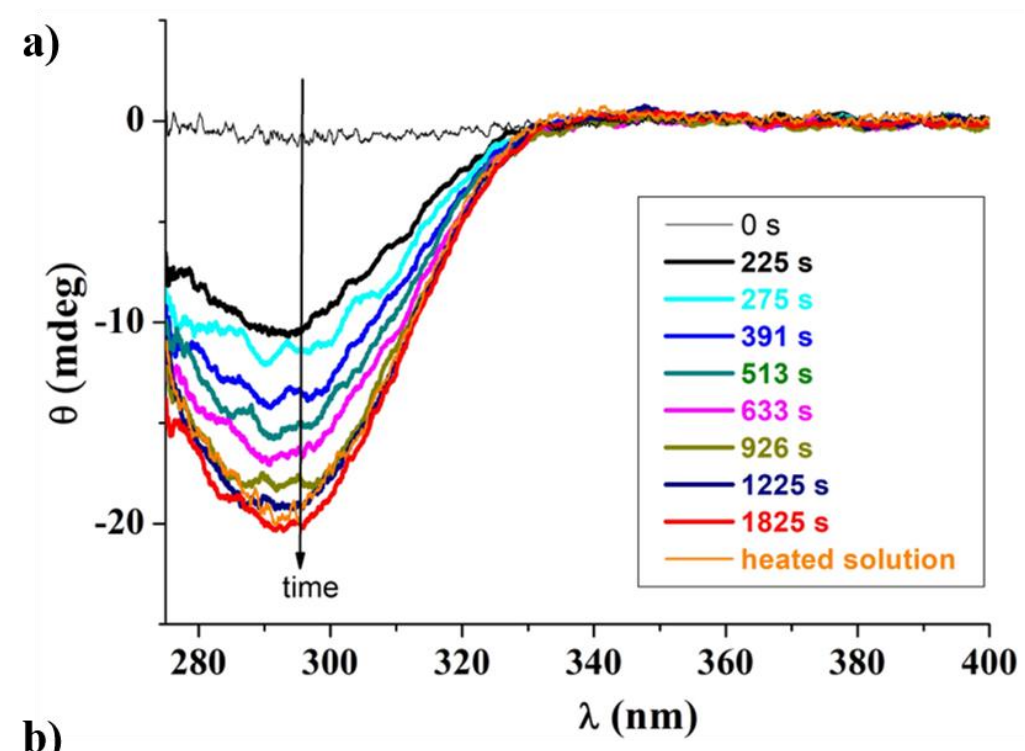

b)

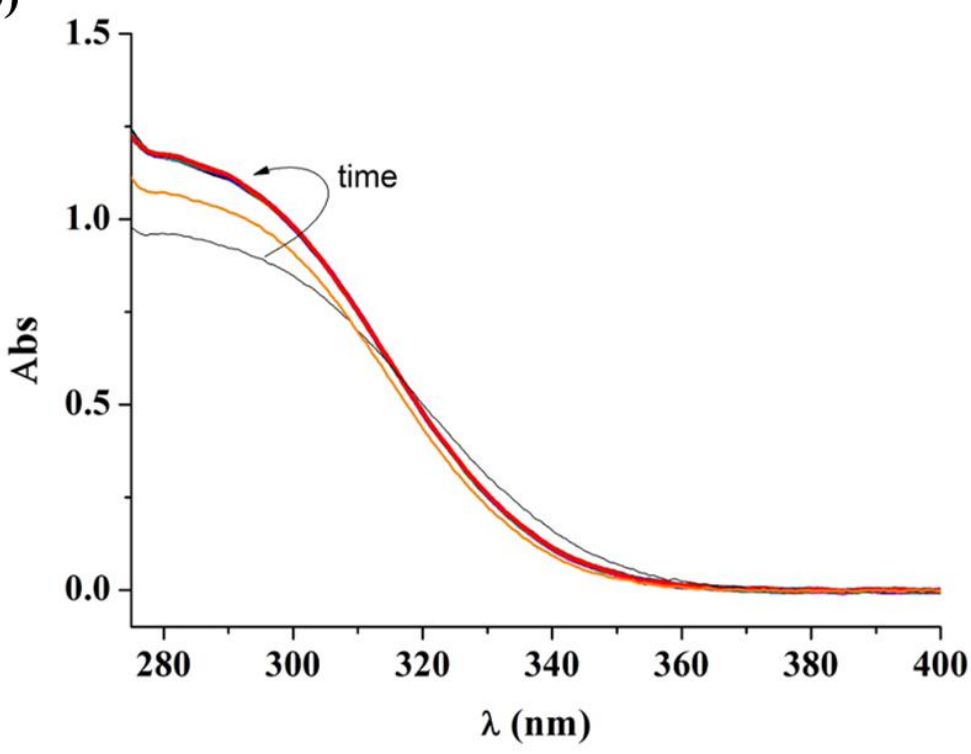

Figure S7 Probing the dynamics of the amplification of chirality by spectroscopic analyses (293 K). CD (a) and UV-Vis absorption analyses (b) of a mixture obtained by adding a-BTA to I1-BTA, $\left[\mathrm{Cu}(\mathrm{OAc})_{2} \cdot \mathrm{H}_{2} \mathrm{O}\right]$ and $(S)$-BTA $\left(\mathrm{f}_{(S) \text {-BTA }}=0.25 \%\right)$. The mixture is stirred for 20 seconds and spectra are recorded at regular times $(0-1825 \mathrm{~s})$. The spectra plotted in orange correspond to analyses performed on a solution of identical composition but heated briefly to reflux prior to analysis.

Composition: l1-BTA $(5.8 \mathrm{mM}),\left[\mathrm{Cu}(\mathrm{OAc})_{2} \bullet \mathrm{H}_{2} \mathrm{O}\right](1.45 \mathrm{mM}),(\boldsymbol{S})$-BTA $\left(29 \mu \mathrm{M}, \mathrm{f}_{(S)-\mathrm{BTA}}=0.25 \%\right)$ and a-BTA $(5.8 \mathrm{mM})$ in toluene. 


\section{General procedures}

Fourier-Transform Infrared (FT-IR) analyses: FT-IR measurements were performed on a Nicolet iS10 spectrometer. Spectra of solutions in toluene were measured in $0.1 \mathrm{~cm}$ (Figures S2a $1.0 \mathrm{mM}-9.2 \mathrm{mM}$ ), $0.05 \mathrm{~cm}$ (Figures 3a-3c and S4) or $0.02 \mathrm{~cm}$ (Figure S2a $21.0 \mathrm{mM}$ ) pathlength $\mathrm{CaF}_{2}$ cells at $293 \mathrm{~K}$ and were corrected for air, solvent and cell absorption.

Circular dichroism (CD) analyses: CD measurements were performed on a Jasco J-1500 spectrometer equipped with a Peltier thermostated cell holder and Xe laser. Data of Fig. 1, Fig. 2, Fig. S1 and Fig. S6ab were recorded at $293 \mathrm{~K}$ with the following parameters: 50 nm. in $^{-1}$ sweep rate, $0.05 \mathrm{~nm}$ data pitch, $2.0 \mathrm{~nm}$ bandwidth, and between 400 and $275 \mathrm{~nm}$ with solutions placed into cylindrical spectrosil quartz cells of 0.10 or $0.20 \mathrm{~mm}$ pathlength (Starna ${ }^{\circledR} 31 / \mathrm{Q} / 0.1$ and 31/Q/0.2, respectively). Data of Fig. S3 were recorded at $293 \mathrm{~K}$ with the following parameters: $50 \mathrm{~nm} . \mathrm{min}^{-1}$ sweep rate, $0.05 \mathrm{~nm}$ data pitch, $8.0 \mathrm{~nm}$ bandwidth, and between 280 and $220 \mathrm{~nm}$ with solutions placed into dismountable quartz cells of $0.01 \mathrm{~mm}$ pathlength. For variable-temperature CD experiments (Fig. S6cd), solutions were placed into cylindrical spectrosil quartz cells of $0.20 \mathrm{~mm}$ pathlength, heated to $373 \mathrm{~K}$ and the ellipticity was recorded at $\lambda=295 \mathrm{~nm}$ during a cooling and a heating process $\left(0.3 \mathrm{~K} \cdot \mathrm{min}^{-1}\right)$. All solutions were pre-heated before measurements. Toluene and cell contributions at the same temperature were subtracted from the obtained signals. For all samples, LD contribution was negligible $(\triangle \mathrm{LD}<0.005 \mathrm{dOD})$ and the shape of the $\mathrm{CD}$ signal was independent of the orientation of the quartz cells. Molar CD values are reported in $\mathrm{L} \cdot \mathrm{mol}^{-1} \cdot \mathrm{cm}^{-1}$ (Figure S1a-S1d) and are expressed as follows: $\Delta \varepsilon=\theta /(32982 \times 1 \times \mathrm{c})$ where $\theta$ is the measured ellipticity (mdeg), 1 is the optical path length in $\mathrm{cm}$, and $\mathrm{c}$ is the 11-BTA concentration in mol. $\mathrm{L}^{-1}$.

UV-Vis analyses: UV-Vis absorption spectra were extracted from CD on each of the above samples and obtained after correction of the absorption of air, solvent, and cell at the same temperature.

Small-angle neutron scattering (SANS) analyses: SANS measurements were made at the LLB (Saclay, France) on the PA20 instrument, at three distance-wavelength combinations to cover the $2 \times 10^{-3}$ to $0.3 \AA^{-1} q$-range, where the scattering vector $\mathrm{q}$ is defined as usual, assuming elastic scattering, as $q=(4 \pi / \lambda) \sin (\theta / 2)$, where $\theta$ is the angle between incident and scattered beam. Data were corrected for the empty cell signal and the solute and solvent incoherent background. A light water standard was used to normalize the scattered intensities to $\mathrm{cm}^{-1}$ units. The data was fitted with the DANSE software SasView. The number $n$ of molecule in the cross-section can be derived from $n_{\mathrm{L}}$ (the number of molecule per unit length) ${ }^{4}$ by assuming an average intermolecular distance of $3.62 \AA$, which is the usual spacing between aromatic rings in BTA helical assemblies. 


\section{Circular Dichroism analyses (Tables S1 to S5)}

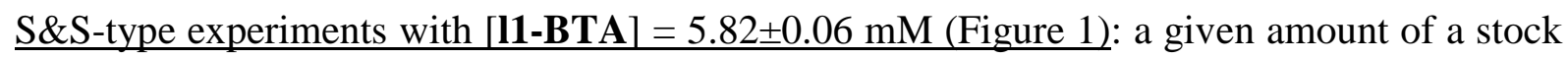
solution prepared by mixing l1-BTA and $\left[\mathrm{Cu}(\mathrm{OAc})_{2} \cdot \mathrm{H}_{2} \mathrm{O}\right]$ was divided in order to get $\left[\mathrm{Cu}(\mathrm{OAc})_{2} \cdot \mathrm{H}_{2} \mathrm{O}\right](0.28 \mathrm{mg}, 1.40 \mu \mathrm{mol})$ and $\mathbf{1 1 - B T A}(4.0 \mathrm{mg}, 5.78 \mu \mathrm{mol})$ in dry THF $(500 \mu \mathrm{L})$ in each vial. The mixture was stirred for 30 minutes. The solvent was removed under vacuum and the tube was further put under vacuum $\left(10^{-3} \mathrm{mbar}\right)$ for 1 hour. The desired amount of $(\boldsymbol{S})$ BTA was added to vials, as well as a-BTA $(6.2 \mathrm{mg}, 5.69 \mu \mathrm{mol})$ when needed. The total solvent volume is set to $1.0 \mathrm{~mL}$.

\begin{tabular}{c|c|c|c|c}
\hline $\begin{array}{c}{[11-\mathrm{BTA}]} \\
(\mathrm{mM})\end{array}$ & $\begin{array}{c}{[(S)-\mathrm{BTA}]} \\
(\mathrm{mM})\end{array}$ & $\begin{array}{c}{[\mathrm{a}-\mathrm{BTA}]} \\
(\mathrm{mM})\end{array}$ & $\begin{array}{c}\mathrm{f}_{(S)} \text {-BTA } \\
(\%)\end{array}$ & $\mathrm{g}^{295} \times 10^{4}$ \\
\hline 5.83 & 0.006 & - & 0.1 & -0.16 \\
\hline 5.83 & 0.03 & - & 0.5 & -0.48 \\
\hline 5.79 & 0.06 & - & 1 & -0.76 \\
\hline 5.76 & 0.56 & - & 9 & -4.1 \\
\hline 5.81 & 1.57 & - & 21 & -5.5 \\
\hline 5.79 & 3.20 & - & 36 & -6.3 \\
\hline 5.80 & 6.35 & - & 52 & -6.9 \\
\hline 5.90 & 0.006 & 5.84 & 0.05 & -4.2 \\
\hline 5.87 & 0.03 & 5.77 & 0.25 & -6.2 \\
\hline 5.76 & 0.06 & 5.78 & 0.5 & -7.0 \\
\hline 5.76 & 0.57 & 5.86 & 5 & -6.9 \\
\hline 5.87 & 1.57 & 5.79 & 12 & -6.8 \\
\hline 5.77 & 3.20 & 5.76 & 22 & -6.9 \\
\hline 5.82 & 6.39 & 5.76 & 36 & -7.0
\end{tabular}

Table S1. Composition and $\mathrm{g}$ values at $\lambda=295 \mathrm{~nm}$ of the S\&S-type experiments analysed by CD spectroscopy $([11-\mathrm{BTA}]=\mathbf{5 . 8 2} \pm 0.06 \mathrm{mM})$.

Diluted MR-type experiments with [11-BTA] $=5.80 \pm 0.07 \mathrm{mM}$ (Figure 2): a given amount of a stock solution prepared by mixing l1-BTA and $\left[\mathrm{Cu}(\mathrm{OAc})_{2} \cdot \mathrm{H}_{2} \mathrm{O}\right]$ was divided in order to get $\left[\mathrm{Cu}(\mathrm{OAc})_{2} \cdot \mathrm{H}_{2} \mathrm{O}\right](0.28 \mathrm{mg}, 1.40 \mu \mathrm{mol})$ and 11-BTA $(4.0 \mathrm{mg}, 5.78 \mu \mathrm{mol})$ in dry THF $(500 \mu \mathrm{L})$ in each vial. The mixture was stirred for 30 minutes. The solvent was removed under vacuum and the tube was further put under vacuum $\left(10^{-3} \mathrm{mbar}\right)$ for 1 hour. A mixture of $(\boldsymbol{S})$-BTA and (R)-BTA monomers with the desired e.e. $(7.5 \mathrm{mg}$ in total, $6.38 \mu \mathrm{mol})$ was added to vials, as well as a-BTA $(7.0 \mathrm{mg}, 6.41 \mu \mathrm{mol})$ when needed. The total solvent volume is set to $1.0 \mathrm{~mL}$. 


\begin{tabular}{|c|c|c|c|c|c|c|}
\hline $\begin{array}{c}\text { [11-BTA] } \\
(\mathrm{mM})\end{array}$ & $\begin{array}{c}{[(S)-\mathrm{BTA}]} \\
(\mathrm{mM})\end{array}$ & $\begin{array}{c}{[(R)-\mathrm{BTA}]} \\
(\mathrm{mM})\end{array}$ & $\begin{array}{c}\text { [a-BTA] } \\
(\mathrm{mM})\end{array}$ & $\begin{array}{c}\mathrm{f}_{(S) \text {-BTA }} \\
(\%)\end{array}$ & $\begin{array}{c}\text { e.e. in } \\
\text { c-BTA } \\
(\%)\end{array}$ & $\mathrm{g}^{295} \times 10^{4}$ \\
\hline 5.83 & 6.47 & 0 & - & 53 & -100 & -6.6 \\
\hline 5.78 & 5.12 & 1.69 & - & 54 & -50 & -5.9 \\
\hline 5.72 & 4.26 & 2.10 & - & 53 & -34 & -5.0 \\
\hline 5.76 & 3.87 & 2.52 & - & 53 & -21 & -3.5 \\
\hline 5.81 & 3.61 & 2.98 & - & 53 & -10 & -1.5 \\
\hline 5.80 & 3.35 & 3.03 & - & 52 & -5 & -0.7 \\
\hline 5.77 & 3.53 & 3.42 & - & 55 & -2 & 0.0 \\
\hline 5.84 & 3.01 & 3.38 & - & 52 & 6 & 1.2 \\
\hline 5.85 & 3.22 & 3.87 & - & 55 & 9 & 2.1 \\
\hline 5.78 & 2.50 & 3.81 & - & 52 & 21 & 3.5 \\
\hline 5.70 & 2.13 & 4.22 & - & 53 & 33 & 4.8 \\
\hline 5.74 & 1.54 & 4.75 & - & 53 & 51 & 5.6 \\
\hline 5.76 & 0 & 6.34 & - & 52 & 100 & 6.8 \\
\hline 5.78 & 6.46 & 0 & 6.36 & 35 & -100 & -6.7 \\
\hline 5.77 & 4.88 & 1.56 & 6.27 & 35 & -52 & -6.5 \\
\hline 5.77 & 4.40 & 2.13 & 6.27 & 35 & -35 & -6.4 \\
\hline 5.80 & 3.91 & 2.61 & 6.28 & 35 & -20 & -6.5 \\
\hline 5.83 & 3.49 & 2.90 & 6.25 & 35 & -9 & -5.5 \\
\hline 5.78 & 3.35 & 3.05 & 6.32 & 35 & -5 & -3.3 \\
\hline 5.82 & 3.07 & 3.10 & 6.79 & 33 & 0.5 & 0.1 \\
\hline 5.80 & 3.05 & 3.36 & 6.19 & 35 & 5 & 5.1 \\
\hline 5.80 & 2.80 & 3.44 & 6.31 & 34 & 10 & 6.7 \\
\hline 5.83 & 2.56 & 3.79 & 6.28 & 35 & 19 & 6.8 \\
\hline 5.81 & 2.08 & 4.34 & 6.27 & 35 & 35 & 6.8 \\
\hline 5.76 & 1.60 & 4.80 & 6.27 & 35 & 50 & 6.8 \\
\hline 5.79 & 0 & 6.33 & 6.33 & 34 & 100 & 6.9 \\
\hline
\end{tabular}

Table S2. Composition and g values at $\lambda=295 \mathrm{~nm}$ of the diluted MR-type experiments analysed by CD spectroscopy $([11-\mathrm{BTA}]=\mathbf{5 . 8 0} \pm 0.07 \mathrm{mM})$.

$\underline{S \& S-t y p e}$ experiments with total concentration in BTA monomers $=5.8 \pm 0.4 \mathrm{mM}$ (Figures S1 $\underline{\mathrm{a} \text { and } \mathrm{b})}$ : a given amount of a stock solution prepared by mixing 11-BTA and $\left[\mathrm{Cu}(\mathrm{OAc})_{2} \cdot \mathrm{H}_{2} \mathrm{O}\right]$ was divided in order to get the desired amounts of $\left[\mathrm{Cu}(\mathrm{OAc})_{2} \cdot \mathrm{H}_{2} \mathrm{O}\right](0.36-1.46 \mu \mathrm{mol})$ and I1BTA $(1.36-5.82 \mu \mathrm{mol})$ in dry THF $(500 \mu \mathrm{L})$ in each vial. The mixture was stirred for 30 minutes. The solvent was removed under vacuum and the tube was further put under vacuum $\left(10^{-3}\right.$ mbar) for 1 hour. The desired amount of $(\boldsymbol{S})$-BTA $(0.007-3.84 \mu \mathrm{mol})$ was added to vials, as well as a-BTA $(1.36-2.90 \mu \mathrm{mol})$ when needed. The total solvent volume is set to 1.0 $\mathrm{mL}$. 


\begin{tabular}{c|c|c|c|c|c}
\hline $\begin{array}{c}{[11-\mathrm{BTA}]} \\
(\mathrm{mM})\end{array}$ & $\begin{array}{c}{[(S)-\mathrm{BTA}]} \\
(\mathrm{mM})\end{array}$ & $\begin{array}{c}{[\mathrm{a}-\mathrm{BTA}]} \\
(\mathrm{mM})\end{array}$ & $\begin{array}{c}{[\mathrm{BTA}]^{\text {tot }}} \\
(\mathrm{mM})\end{array}$ & $\begin{array}{c}\mathrm{f}_{(S)-\mathrm{BTA}} \\
(\%)\end{array}$ & $\mathrm{g}^{295} \times 10^{4}$ \\
\hline 5.82 & 0.007 & - & 5.82 & 0.1 & 0.01 \\
\hline 5.79 & 0.02 & - & 5.81 & 0.3 & 0.12 \\
\hline 5.76 & 0.03 & - & 5.79 & 0.6 & -0.5 \\
\hline 5.75 & 0.06 & - & 5.82 & 1 & -0.7 \\
\hline 5.30 & 0.58 & - & 5.87 & 10 & -3.3 \\
\hline 4.52 & 1.41 & - & 5.93 & 24 & -4.4 \\
\hline 3.77 & 2.25 & - & 6.01 & 37 & -5.2 \\
\hline 2.77 & 3.33 & - & 6.10 & 55 & -5.4 \\
\hline 2.33 & 3.84 & - & 6.17 & 62 & -4.8 \\
\hline 2.90 & 0.006 & 2.90 & 5.81 & 0.1 & -4.1 \\
\hline 2.89 & 0.02 & 2.89 & 5.81 & 0.3 & -5.7 \\
\hline 2.89 & 0.03 & 2.89 & 5.81 & 0.6 & -6.4 \\
\hline 2.87 & 0.06 & 2.87 & 5.81 & 1 & -6.7 \\
\hline 2.65 & 0.58 & 2.64 & 5.87 & 10 & -6.5 \\
\hline 2.27 & 1.41 & 2.27 & 5.95 & 24 & -6.4 \\
\hline 1.89 & 2.25 & 1.89 & 6.04 & 37 & -6.0 \\
\hline 1.36 & 3.26 & 1.36 & 5.98 & 55 & -6.1 \\
\hline
\end{tabular}

Table S3. Composition of the S\&S-type experiments analysed by CD spectroscopy (total BTA monomer concentration $=5.8 \pm 0.4 \mathrm{mM}$ ).

The solutions highlighted in orange have been used for VT-CD experiments (Figure S6).

Diluted MR-type experiments with total concentration in BTA monomers $=5.8 \pm 0.1 \mathrm{mM}$ (Figures S1 c and d): a given amount of a stock solution prepared by mixing 11-BTA and $\left[\mathrm{Cu}(\mathrm{OAc})_{2} \cdot \mathrm{H}_{2} \mathrm{O}\right]$ was divided in order to get $\left[\mathrm{Cu}(\mathrm{OAc})_{2} \cdot \mathrm{H}_{2} \mathrm{O}\right](0.7 \mu \mathrm{mol}$ and $0.35 \mu \mathrm{mol}$ without and with a-BTA respectively) and 11-BTA $(2.79 \pm 0.03 \mu \mathrm{mol}$ and $1.39 \pm 0.03 \mu \mathrm{mol}$ without and with a-BTA respectively) in dry THF $(500 \mu \mathrm{L})$ in each vial. The mixture was stirred for 30 minutes. The solvent was removed under vacuum and the tube was further put under vacuum $\left(10^{-3} \mathrm{mbar}\right)$ for 1 hour. A mixture of $(\boldsymbol{S})$-BTA and $(\boldsymbol{R})$-BTA monomers $\left(3.00 \pm 0.03 \mu \mathrm{mol}, \mathrm{f}_{\mathrm{c}-\mathrm{BTA}}=0.52\right)$ with the desired e.e. was added to vials, as well as aBTA $(1.39 \pm 0.03 \mu \mathrm{mol})$ when needed. The total solvent volume is set to $1.0 \mathrm{~mL}$. 


\begin{tabular}{|c|c|c|c|c|c|c|}
\hline $\begin{array}{c}\text { [11-BTA] } \\
(\mathrm{mM})\end{array}$ & $\begin{array}{c}{[(S)-\mathrm{BTA}]} \\
(\mathrm{mM})\end{array}$ & $\begin{array}{c}{[(R)-\mathrm{BTA}]} \\
\quad(\mathrm{mM})\end{array}$ & $\begin{array}{c}\text { [a-BTA] } \\
(\mathrm{mM})\end{array}$ & $\begin{array}{c}\left.{ }_{[\mathrm{BTA}}\right]^{\mathrm{tot}} \\
(\mathrm{mM})\end{array}$ & $\begin{array}{l}\text { e.e. in c- } \\
\text { BTA }(\%)\end{array}$ & $\mathrm{g}^{295} \times 10^{4}$ \\
\hline 2.80 & 3.00 & 0 & - & 5.81 & -100 & -5.0 \\
\hline 2.80 & 2.25 & 0.75 & - & 5.79 & -50 & -4.3 \\
\hline 2.78 & 2.00 & 1.00 & - & 5.77 & -33 & -3.5 \\
\hline 2.79 & 1.80 & 1.20 & - & 5.78 & -20 & -2.9 \\
\hline 2.79 & 1.64 & 1.36 & - & 5.77 & -10 & -1.2 \\
\hline 2.77 & 1.58 & 1.42 & - & 5.75 & -5 & -0.8 \\
\hline 2.77 & 1.54 & 1.46 & - & 5.75 & -3 & -0.4 \\
\hline 2.77 & 1.50 & 1.50 & - & 5.75 & 0 & -0.1 \\
\hline 2.79 & 1.46 & 1.54 & - & 5.78 & 3 & 0.4 \\
\hline 2.80 & 1.41 & 1.59 & - & 5.80 & 6 & 1.0 \\
\hline 2.82 & 1.33 & 1.67 & - & 5.84 & 11 & 1.4 \\
\hline 2.80 & 1.18 & 1.82 & - & 5.80 & 21 & 2.6 \\
\hline 2.80 & 1.00 & 2.00 & - & 5.80 & 33 & 3.8 \\
\hline 2.80 & 1.76 & 2.24 & - & 5.81 & 49 & 4.4 \\
\hline 2.78 & 0 & 3.00 & - & 5.76 & 100 & 5.0 \\
\hline 1.39 & 3.00 & 0 & 1.39 & 5.77 & -100 & -6.0 \\
\hline 1.39 & 2.25 & 0.75 & 1.39 & 5.75 & -50 & -6.1 \\
\hline 1.40 & 1.98 & 1.02 & 1.40 & 5.80 & -32 & -6.0 \\
\hline 1.41 & 1.80 & 1.20 & 1.41 & 5.83 & -20 & -6.0 \\
\hline 1.42 & 1.63 & 1.37 & 1.42 & 5.86 & -9 & -5.8 \\
\hline 1.39 & 1.57 & 1.43 & 1.39 & 5.76 & -4 & -4.5 \\
\hline 1.39 & 1.53 & 1.47 & 1.39 & 5.76 & -2 & -2.5 \\
\hline 1.39 & 1.49 & 1.51 & 1.39 & 5.76 & 0 & 0.3 \\
\hline 1.39 & 1.46 & 1.54 & 1.39 & 5.77 & 2 & 3.0 \\
\hline 1.40 & 1.43 & 1.57 & 1.40 & 5.79 & 5 & 4.8 \\
\hline 1.39 & 1.35 & 1.65 & 1.39 & 5.76 & 10 & 5.7 \\
\hline 1.40 & 1.18 & 1.82 & 1.40 & 5.79 & 21 & 5.8 \\
\hline 1.40 & 1.00 & 2.00 & 1.40 & 5.80 & 33 & 5.9 \\
\hline 1.40 & 0.75 & 2.25 & 1.40 & 5.81 & 50 & 5.9 \\
\hline 1.39 & 0 & 3.00 & 1.39 & 5.76 & 100 & 5.9 \\
\hline
\end{tabular}

Table S4. Composition of the diluted MR-type experiments analysed by CD spectroscopy (total BTA monomer concentration $=\mathbf{5 . 8} \pm \mathbf{0 . 1} \mathrm{mM}$ ).

CD spectroscopy analyses aimed at probing the dynamic nature of the BTA co-assemblies (Figure S7): a given amount of a stock solution prepared by mixing 11-BTA and $\left[\mathrm{Cu}(\mathrm{OAc})_{2} \cdot \mathrm{H}_{2} \mathrm{O}\right]$ was divided in order to get $\left[\mathrm{Cu}(\mathrm{OAc})_{2} \cdot \mathrm{H}_{2} \mathrm{O}\right](0.28 \mathrm{mg}, 1.40 \mu \mathrm{mol})$ and I1- 
BTA $(4.0 \mathrm{mg}, 5.78 \mu \mathrm{mol})$ in dry THF $(500 \mu \mathrm{L})$ in the vial. The mixture was stirred for 30 minutes. The solvent was removed under vacuum and the tube was further put under vacuum $\left(10^{-3} \mathrm{mbar}\right)$ for 1 hour. $25.1 \mathrm{mg}$ of the $1.0 \mathrm{mM}$ stock solution of $(\boldsymbol{S})$-BTA $\left(0.03 \mu \mathrm{mol}, \mathrm{f}_{(S) \text {-BTA }}=\right.$ $0.5 \%)$ was added to the vial and the total solvent volume is set to $1.0 \mathrm{~mL}$. a-BTA $(6.2 \mathrm{mg}$, $5.69 \mu \mathrm{mol})$ in toluene $(100 \mu \mathrm{L})$ was added and the mixture was stirred for 20 seconds. Then, an aliquot $(\mathrm{V} \approx 200 \mu \mathrm{L})$ was taken, introduced in a Starna ${ }^{\circledR} 31 / \mathrm{Q} / 0.1$ quartz cell and analyzed by $\mathrm{CD}$ spectroscopy at regular times $(0-1825 \mathrm{~s}$, time of analysis by $\mathrm{CD}=37.5 \mathrm{~s})$.

\begin{tabular}{c|c}
\hline time $(\mathrm{s})$ & $\mathrm{g}^{295} \times 10^{4}$ \\
\hline 0 & -0.4 \\
\hline 225 & -3.0 \\
\hline 275 & -3.3 \\
\hline 391 & -3.9 \\
\hline 513 & -4.3 \\
\hline 633 & -4.7 \\
\hline 926 & -5.1 \\
\hline 1225 & -5.4 \\
\hline 1825 & -5.7
\end{tabular}

Table S5. CD analyses aimed at probing the dynamic nature of the S\&S-type catalytic system.

The indicated time is the average time between the beginning and the end of the $\mathrm{CD}$ analysis.

Preparation of the solutions for CD analyses of $(\boldsymbol{S})$-BTA, a-BTA and their mixtures (Figure S3): $14 \mathrm{mM}$ solutions of (S)-BTA and c-BTA were prepared by dissolving the corresponding solids in toluene. Their mixtures were prepared by mixing the desired volume of these mother solutions. Samples were heated prior to analysis. 


\section{Preparation of solutions for FT-IR analyses}

Preparation of the solutions for FT-IR analyses of a-BTA at different concentrations (Figures S2a): $1.0 \mathrm{mM}, 2.0 \mathrm{mM}, 5.5 \mathrm{mM}, 9.2 \mathrm{mM}$ and $21.0 \mathrm{mM}$ solutions of a-BTA were prepared by dissolving directly the desired amount of a-BTA in toluene. Samples were heated prior to analysis.

Preparation of the solution for the FT-IR analysis of the 1:1 mixture between [11-BTA + $\left.\left[\mathrm{Cu}(\mathrm{OAc})_{2} \cdot \mathrm{H}_{2} \mathrm{O}\right]\right\}$ and a-BTA (Figure 3a): The 1:1 mixture was prepared by mixing a similar volume of their $5.8 \mathrm{mM}$ solutions. Sample was heated prior to analysis.

Preparation of the solutions for FT-IR analyses of $(\boldsymbol{S})$-BTA, a-BTA and their 1:1 mixture (Figures $3 \mathrm{a}$ and $3 \mathrm{~b}$ ): $5.8 \mathrm{mM}$ solutions of $(\boldsymbol{S})$-BTA and c-BTA were prepared by dissolving the corresponding solids in toluene. Their 1:1 mixture was prepared by mixing a similar volume of these solutions. Samples were heated prior to analysis.

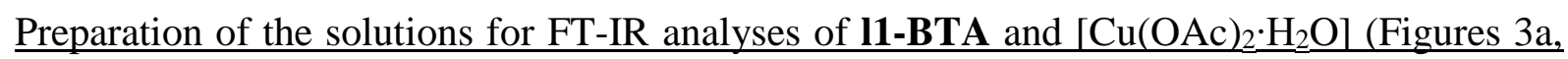
$\underline{3 c}$ and S4a): a given amount of a stock solution prepared by mixing 11-BTA and $\left[\mathrm{Cu}(\mathrm{OAc})_{2} \cdot \mathrm{H}_{2} \mathrm{O}\right]$ was divided in order to get $\left[\mathrm{Cu}(\mathrm{OAc})_{2} \cdot \mathrm{H}_{2} \mathrm{O}\right](0.28 \mathrm{mg}, 1.40 \mu \mathrm{mol})$ and 11BTA $(4.0 \mathrm{mg}, 5.78 \mu \mathrm{mol})$ in dry THF $(500 \mu \mathrm{L})$ in the vial. The mixture was stirred for 30 minutes. The solvent was removed under vacuum and the tube was further put under vacuum $\left(10^{-3} \mathrm{mbar}\right)$ for 1 hour. Toluene was added $(1.0 \mathrm{~mL})$ and the sample was heated prior to analysis.

Preparation of the solutions for FT-IR analyses of the mixture between 11-BTA, $\left[\mathrm{Cu}(\mathrm{OAc})_{2} \cdot \mathrm{H}_{2} \mathrm{O}\right],(\boldsymbol{S})$-BTA and a-BTA (Figure $3 \mathrm{c}$ ): a given amount of a stock solution prepared by mixing l1-BTA and $\left[\mathrm{Cu}(\mathrm{OAc})_{2} \cdot \mathrm{H}_{2} \mathrm{O}\right]$ was divided in order to get $\left[\mathrm{Cu}(\mathrm{OAc})_{2} \cdot \mathrm{H}_{2} \mathrm{O}\right](0.28 \mathrm{mg}, 1.40 \mu \mathrm{mol})$ and 11-BTA $(4.0 \mathrm{mg}, 5.78 \mu \mathrm{mol})$ in dry THF $(500 \mu \mathrm{L})$ in the vial. The mixture was stirred for 30 minutes. The solvent was removed under vacuum and the tube was further put under vacuum $\left(10^{-3} \mathrm{mbar}\right)$ for 1 hour. $503 \mathrm{mg}$ of a $1.0 \mathrm{mM}$ stock solution of $(\boldsymbol{S})$-BTA $(0.58 \mu \mathrm{mol})$ in toluene was added as well as a-BTA $(6.2 \mathrm{mg}, 5.69 \mu \mathrm{mol})$ and the total amount of toluene was set equal to $1000 \mu \mathrm{L}$. The sample was heated prior to analysis.

Preparation of the solutions for FT-IR analyses of the mixture between 11-BTA, $\left[\mathrm{Cu}(\mathrm{OAc})_{2} \cdot \mathrm{H}_{2} \mathrm{O}\right]$ and $(\boldsymbol{S})$-BTA (Figure $\mathrm{S} 4 \mathrm{a}$ ): a given amount of a stock solution prepared by mixing l1-BTA and $\left[\mathrm{Cu}(\mathrm{OAc})_{2} \cdot \mathrm{H}_{2} \mathrm{O}\right]$ was divided in order to get $\left[\mathrm{Cu}(\mathrm{OAc})_{2} \cdot \mathrm{H}_{2} \mathrm{O}\right](0.28 \mathrm{mg}$, $1.40 \mu \mathrm{mol})$ and 11-BTA $(4.0 \mathrm{mg}, 5.78 \mu \mathrm{mol})$ in dry THF $(500 \mu \mathrm{L})$ in the vial. The mixture was stirred for 30 minutes. The solvent was removed under vacuum and the tube was further put under vacuum $\left(10^{-3}\right.$ mbar) for 1 hour. $503 \mathrm{mg}$ of a $1.0 \mathrm{mM}$ stock solution of (S)-BTA $(0.58 \mu \mathrm{mol})$ in toluene was added to the vial and the total amount of toluene was set equal to $1000 \mu \mathrm{L}$. The sample was heated prior to analysis. 


\section{Preparation of solutions for SANS analyses}

Preparation of the solutions of a-BTA (Figures $3 \mathrm{c}$ and S2b): [a-BTA] $=5.91$ g.L $\mathrm{L}^{-1}$ : a-BTA $(7.1 \mathrm{mg}, 6.51 \mu \mathrm{mol})$ was introduced in a vial as well as toluene-d $8(1.13 \mathrm{~g}, 1.20 \mathrm{~mL})$. [aBTA $]=9.83 \mathrm{~g} \cdot \mathrm{L}^{-1}: \mathbf{a - B T A}(11.9 \mathrm{mg}, 10.9 \mu \mathrm{mol})$ was introduced in a vial as well as toluene- $\mathrm{d}_{8}$ $(1.13 \mathrm{~g}, 1.20 \mathrm{~mL})$. The samples were heated to ensure solubilisation.

Preparation of the solutions of 11-BTA (Figure 3c): [11-BTA] $=5.98$ g.L - $^{-1}$ : 11-BTA $(7.3 \mathrm{mg}$, $10.6 \mu \mathrm{mol})$ was introduced in a vial as well as toluene- $\mathrm{d}_{8}(1.14 \mathrm{~g}, 1.20 \mathrm{~mL})$. The sample was heated prior to analysis.

Preparation of the solutions of the mixture between I1-BTA, $\left[\mathrm{Cu}(\mathrm{OAc})_{2} \cdot \underline{\mathrm{H}}_{2} \mathrm{O}\right],(\boldsymbol{S})$-BTA and a-BTA (Figure 3c): a given amount of a stock solution prepared by mixing 11-BTA and $\left[\mathrm{Cu}(\mathrm{OAc})_{2} \cdot \mathrm{H}_{2} \mathrm{O}\right]$ was divided in order to get $\left[\mathrm{Cu}(\mathrm{OAc})_{2} \cdot \mathrm{H}_{2} \mathrm{O}\right](0.36 \mathrm{mg}, 1.80 \mu \mathrm{mol})$ and 11BTA $(4.74 \mathrm{mg}, 6.85 \mu \mathrm{mol})$ in dry THF $(500 \mu \mathrm{L})$ in the vial. The mixture was stirred for 30 minutes. The solvent was removed under vacuum and the tube was further put under vacuum $\left(10^{-3}\right.$ mbar) for 1 hour. $94.3 \mathrm{mg}$ of a $8.16 \mathrm{mg} / \mathrm{mL}$ stock solution of $(\boldsymbol{S})$-BTA $(0.82 \mathrm{mg}, 0.7$ $\mu \mathrm{mol})$ in toluene- $\mathrm{d}_{8}$ and a-BTA $(3.92 \mathrm{mg}, 3.60 \mu \mathrm{mol})$ were added to the vial and the total amount of toluene- $\mathrm{d}_{8}$ was set equal to $1.13 \mathrm{~g}(1.20 \mathrm{~mL})$. The sample was heated prior to analysis. 


\section{Catalytic experiments (Tables S6 to S9)}

In all catalytic experiments a pre-catalytic mixture composed of the ligand, the copper salt and the substrate was prepared as follows: a tube was loaded with $\left[\mathrm{Cu}(\mathrm{OAc})_{2} \cdot \mathrm{H}_{2} \mathrm{O}\right](0.5 \mathrm{mg}$, $2.55 \mu \mathrm{mol}, 3.0 \mathrm{~mol} \%)$ and 11-BTA $(6.9 \mathrm{mg}, 10.0 \mu \mathrm{mol}, 12.0 \mathrm{~mol} \%)$ in dry THF $(500 \mu \mathrm{L})$ and the mixture was stirred for 30 minutes. The solvent was removed under vacuum and the tube was further put under vacuum $\left(10^{-3} \mathrm{mbar}\right)$ for 1 hour. Then 1-(4-nitrophenyl)ethanone (14.0 $\mathrm{mg}, 0.085 \mathrm{mmol}, 100 \mathrm{~mol} \%$ ) was added before flushing the tube with argon for 10 seconds.

Then, the desired amount of or the mixture of $(\boldsymbol{S})$-BTA and $(\boldsymbol{R})$-BTA monomers with the desired e.e. as well as a-BTA $(10.9 \mathrm{mg}, 10.0 \mu \mathrm{mol}, 12.0 \mathrm{~mol} \%)$ were added to the tube as well as dry toluene. The total solvent volume was set equal to $600 \mu \mathrm{L}$ (except for the experiments with 11-BTA $=32.2 \mathrm{mM}$ for which the volume $=300 \mu \mathrm{L}$ ). The mixture was stirred for $15 \mathrm{~min}$ at room temperature, and then the solution was briefly heated to reflux. After cooling down to $293 \mathrm{~K}, \mathrm{PhSiH}_{3}(21.0 \mu \mathrm{L}, 0.17 \mathrm{mmol}, 200 \mathrm{~mol} \%)$ was added to the tube and the reaction mixture was stirred for 12 hours before being hydrolyzed with aqueous $\mathrm{HCl}$ and analyzed by ${ }^{1} \mathrm{H}$ NMR and chiral GC.

Chiral GC analyses: The optical purity was determined by GC analysis: Chiral Cyclosil-B column, $30 \mathrm{~m} \times 250 \mu \mathrm{m} \times 0.25 \mu \mathrm{m}$, inlet pressure $=12.6$ psi. Injection temperature $=250^{\circ} \mathrm{C}$; detector temperature $=300^{\circ} \mathrm{C}$; column temperature $=145^{\circ} \mathrm{C}$. Retention time: $17.9 \mathrm{~min}(1-(4-$ nitrophenyl)ethanone), $47.6 \mathrm{~min}\left((R)\right.$-enantiomer), $49.9 \mathrm{~min}((S)$-enantiomer $) .^{5}$

S\&S-type type catalytic experiments (Figure 4a): A $10.0 \mathrm{mM}$ stock solution of $(\boldsymbol{S})$-BTA was prepared by mixing $11.7 \mathrm{mg}$ of $(\boldsymbol{S})$-BTA and $1.0 \mathrm{~mL}(867 \mathrm{mg})$ of toluene. Then $1.0 \mathrm{mM}$ and $0.1 \mathrm{mM}$ stock solutions were prepared by dilution. Then the desired amount of $(\boldsymbol{S})$-BTA monomers was introduced: $86.7 \mathrm{mg}$ of the $0.1 \mathrm{mM}$ stock solution $(0.01 \mu \mathrm{mol}, 16 \mu \mathrm{M}), 43.4$ $\mathrm{mg}$ of the $1.0 \mathrm{mM}$ stock solution $(0.05 \mu \mathrm{mol}, 80 \mu \mathrm{M}), 86.7 \mathrm{mg}$ of the $1.0 \mathrm{mM}$ stock solution $(0.10 \mu \mathrm{mol}, 160 \mu \mathrm{M}), 86.7 \mathrm{mg}$ of the $10.0 \mathrm{mM}$ stock solution $(1.0 \mu \mathrm{mol}, 1.6 \mathrm{mM}), 238.4 \mathrm{mg}$ of the $10.0 \mathrm{mM}$ stock solution $(2.75 \mu \mathrm{mol}, 4.4 \mathrm{mM}), 6.5 \mathrm{mg}(5.53 \mu \mathrm{mol}, 9.3 \mathrm{mM})$ of solid (S)-BTA, $12.9 \mathrm{mg}(11.0 \mu \mathrm{mol}, 18.4 \mathrm{mM})$ of solid $(\boldsymbol{S})$-BTA and $25.4 \mathrm{mg}(21.6 \mu \mathrm{mol}, 34.8$ $\mathrm{mM})$ of solid $(\boldsymbol{S})$-BTA.

The concentrations in 11-BTA and $\left[\mathrm{Cu}(\mathrm{OAc})_{2} \cdot \mathrm{H}_{2} \mathrm{O}\right]$ are set constant to $16.1 \mathrm{mM}$ and $4.0 \mathrm{mM}$, respectively. The concentrations in 1-(4-nitrophenyl)ethanone and $\mathrm{PhSiH}_{3}$ are set constant to $137 \mathrm{mM}$ and $274 \mathrm{mM}$, respectively. 


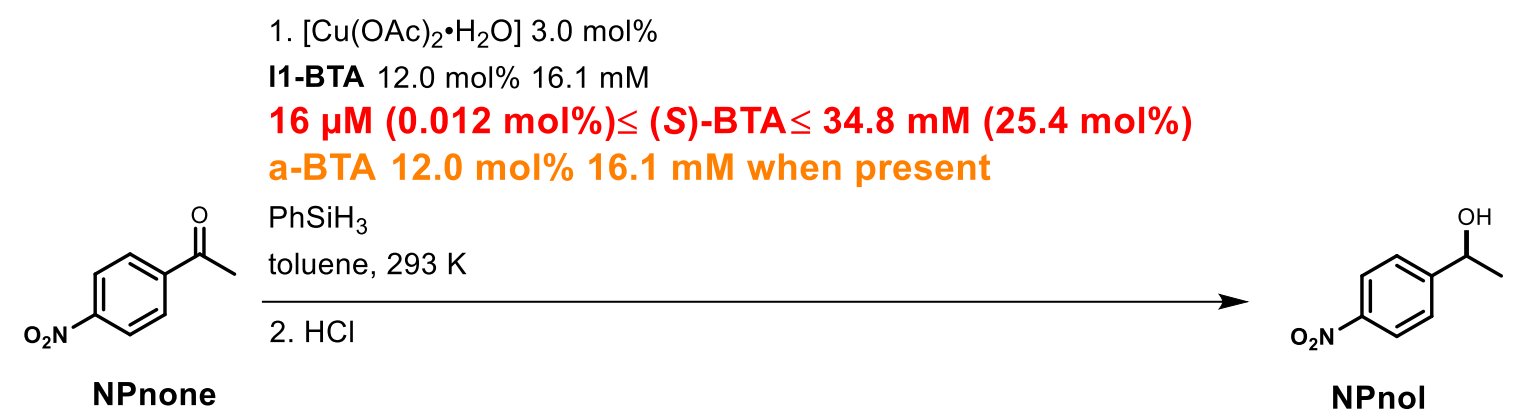

\begin{tabular}{c|c|c|c|c|c}
\hline Entry & $\begin{array}{c}{[(S)-\mathrm{BTA}]} \\
(\mathrm{mM})\end{array}$ & $\begin{array}{c}(S)-\mathrm{BTA} \\
\text { loading in mol\% }\end{array}$ & $\begin{array}{c}{[\mathrm{a}-\mathrm{BTA}]} \\
(\mathrm{mM})\end{array}$ & $\begin{array}{c}\mathrm{f}_{(S) \text {-BTA }}(\%) \\
\text { e.e. } \pm 1 \% \text { in NPnol } \\
(\%)\end{array}$ \\
\hline 1 & 0.016 & 0.01 & - & 0.1 & 0.6 \\
\hline 2 & 0.08 & 0.06 & - & 0.5 & 0.5 \\
\hline 4 & 0.16 & 0.1 & - & 0.9 & -4.2 \\
\hline 5 & 1.6 & 1.2 & - & 9 & -17.5 \\
\hline 6 & 4.4 & 3.2 & - & 22 & -41.6 \\
\hline 7 & 9.3 & 6.7 & - & 36 & -53.4 \\
\hline 8 & 18.4 & 12.9 & - & 52 & -57.6 \\
\hline 9 & 0.016 & 0.01 & 16.1 & 0.05 & -35.1 \\
\hline 10 & 0.16 & 0.06 & 16.1 & 0.25 & -50.4 \\
\hline 11 & 1.6 & 0.1 & 16.1 & 0.5 & -51.4 \\
\hline 12 & 4.4 & 1.2 & 16.1 & 5 & -51.8 \\
\hline 13 & 9.3 & 3.2 & 16.1 & 12 & -51.2 \\
\hline 14 & 18.4 & 6.7 & 16.1 & 22 & -51.6 \\
\hline 15 & 34.8 & 12.9 & 16.1 & 35 & -51.6 \\
\hline
\end{tabular}

Table S6. S\&S-type catalytic experiments: composition and catalytic result for each mixture (Figure 4a).

$\mathrm{f}_{(S)-\mathrm{BTA}}=[(S)-\mathrm{BTA}] /([(S)-\mathrm{BTA}]+[11-\mathrm{BTA}]+[\mathrm{a}-\mathrm{BTA}])$. Catalytic loading in $(S)-\mathrm{BTA}=[(S)-\mathrm{BTA}] /[1-(4-$ nitrophenyl)ethanone]. Conversion $>99 \%$ was obtained for all catalytic experiments. The optical purity of NPnol was determined by GC analysis, e.e. are set as positive and negative when $(S)$-NPnol and $(R)$-NPnol are the major enantiomers, respectively.

Diluted MR-type type catalytic experiments (Figure 4c): $110.0 \mathrm{mM}$ stock solutions of $(\boldsymbol{S})$ BTA and $(\boldsymbol{R})$-BTA were prepared by mixing $117.0 \mathrm{mg}$ of the respective monomers and 1.0 $\mathrm{mL}(867 \mathrm{mg}$ ) of toluene. These $110.0 \mathrm{mM}$ stock solutions were mixed together in order to get the solutions with desired e.e. Then $86.7 \mathrm{mg}$ of these $110.0 \mathrm{mM}$ solutions of c-BTA (11.0 $\mu \mathrm{mol}, 17.7 \mathrm{mM}, 12.9 \mathrm{~mol} \%, \mathrm{f}_{\mathrm{c}-\mathrm{BTA}}=0.52$ and 0.35 without and with a-BTA respectively) was added to the tube.

The concentrations in 11-BTA and $\left[\mathrm{Cu}(\mathrm{OAc})_{2} \cdot \mathrm{H}_{2} \mathrm{O}\right]$ are set constant to $16.1 \mathrm{mM}$ and $4.0 \mathrm{mM}$, respectively. The concentrations in 1-(4-nitrophenyl)ethanone and $\mathrm{PhSiH}_{3}$ are set constant to $137 \mathrm{mM}$ and $274 \mathrm{mM}$, respectively. 


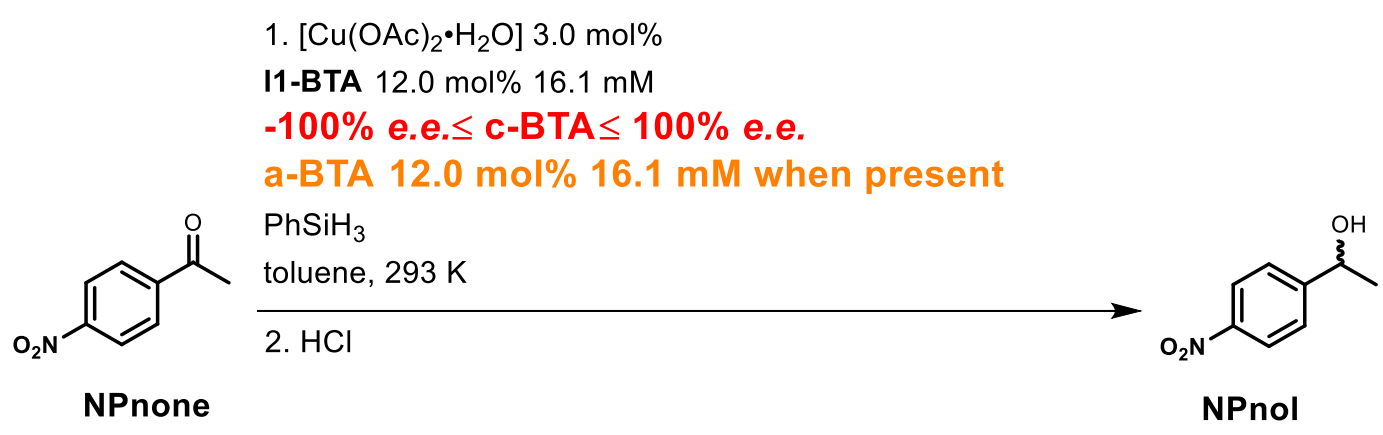

\begin{tabular}{|c|c|c|c|c|c|}
\hline Entry & $\begin{array}{l}{[(S)-\mathrm{BTA}]} \\
(\mathrm{mM})\end{array}$ & $\begin{array}{l}{[(R)-\mathrm{BTA}]} \\
(\mathrm{mM})\end{array}$ & $\begin{array}{c}\text { [a-BTA] } \\
(\mathrm{mM})\end{array}$ & $\begin{array}{c}\text { e.e. in c-BTA } \\
(\%)\end{array}$ & $\begin{array}{c}\text { e.e. } \pm 1 \% \text { in NPnol } \\
(\%)\end{array}$ \\
\hline 1 & 0 & 17.7 & - & 100 & 56.6 \\
\hline 2 & 4.6 & 13.1 & - & 50 & 55.0 \\
\hline 3 & 5.9 & 11.8 & - & 33 & 44.4 \\
\hline 4 & 7.1 & 10.6 & - & 20 & 29.8 \\
\hline 5 & 8.0 & 9.7 & - & 10 & 16.8 \\
\hline 6 & 8.4 & 9.3 & - & 5 & 7.6 \\
\hline 7 & 8.85 & 8.85 & - & 0 & 0 \\
\hline 8 & 9.3 & 8.4 & - & -5 & -7.0 \\
\hline 9 & 9.7 & 8.0 & - & -10 & -12.8 \\
\hline 10 & 10.6 & 7.1 & - & -20 & -28.8 \\
\hline 11 & 11.8 & 5.9 & - & -33 & -48.6 \\
\hline 12 & 13.1 & 4.6 & - & -50 & -52.4 \\
\hline 13 & 17.7 & 0 & - & -100 & -57.6 \\
\hline 14 & 0 & 17.7 & 16.1 & 100 & 52.4 \\
\hline 15 & 4.6 & 13.1 & 16.1 & 50 & 51.8 \\
\hline 16 & 5.9 & 11.8 & 16.1 & 33 & 52.0 \\
\hline 17 & 7.1 & 10.6 & 16.1 & 20 & 51.0 \\
\hline 18 & 8.0 & 9.7 & 16.1 & 10 & 45.6 \\
\hline 19 & 8.4 & 9.3 & 16.1 & 5 & 26.0 \\
\hline 20 & 8.85 & 8.85 & 16.1 & 0 & 0.8 \\
\hline 21 & 9.3 & 8.4 & 16.1 & -5 & -24.4 \\
\hline 22 & 9.7 & 8.0 & 16.1 & -10 & -42.8 \\
\hline 23 & 10.6 & 7.1 & 16.1 & -20 & -51.0 \\
\hline 24 & 11.8 & 5.9 & 16.1 & -33 & -50.6 \\
\hline 25 & 13.1 & 4.6 & 16.1 & -50 & -51.4 \\
\hline 26 & 17.7 & 0 & 16.1 & -100 & -52.0 \\
\hline
\end{tabular}

Table S7. Diluted MR-type catalytic experiments: composition and catalytic result for each mixture (Figure 4c).

Conversion $>99 \%$ was obtained for all catalytic experiments. The optical purity of NPnol was determined by GC analysis, e.e. are set as positive and negative when $(S)$-NPnol and $(R)$-NPnol are the major enantiomers, respectively. 
Optimization of S\&S-type type catalytic experiments (Tables 2 and S8): Catalytic solutions were prepared as indicated above with $0.05 \mu \mathrm{mol}$ of $(\boldsymbol{S})$-BTA or $(\boldsymbol{R})$-BTA corresponding to a concentration of $80 \mu \mathrm{M}$. The screened parameters are: i) the nature of the BTA ligand (11BTA or 12-BTA), ii) the temperature (293 K or $200 \mathrm{~K})$, and iii) the concentration in NPnone $(137-1096 \mathrm{mM})$.

1. $\left[\mathrm{Cu}(\mathrm{OAc})_{2} \cdot \mathrm{H}_{2} \mathrm{O}\right] 4.0 \mathrm{mM}$

\begin{tabular}{|c|c|c|c|c|c|c|}
\hline & & $\begin{array}{l}\text { I1-BT } \\
{[(S)-\mathrm{E}} \\
\mathrm{a}-\mathrm{BT} \\
\mathrm{PhSiH} \\
\text { toluen }\end{array}$ & $\begin{array}{l}\text { or I2-BT } \\
\mathrm{A}] \text { or }[(R \\
16.1 \mathrm{mM} \\
293 \mathrm{~K} \text { or }\end{array}$ & $\begin{array}{l}16.1 \mathrm{mM} \\
\text { BTA] } 80 \mu \\
\text { hen prese } \\
0 \mathrm{~K}\end{array}$ & & \\
\hline & $\begin{array}{r}\text { NPnone } \\
137 \mathrm{mM}-109\end{array}$ & & & & NP & \\
\hline Entry & BTA ligand & $\mathrm{T}$ & $\begin{array}{c}{[\mathrm{a}-\mathrm{BTA}]} \\
(\mathrm{mM})\end{array}$ & $\begin{array}{c}\text { [NPnone] } \\
(\mathrm{mM})\end{array}$ & $\begin{array}{l}\text { c-BTA loading } \\
\text { in ppm }\end{array}$ & $\begin{array}{l}\text { e.e. } \pm 1 \% \text { in } \\
\text { NPnol }(\%)\end{array}$ \\
\hline 1 & 11-BTA & $293 \mathrm{~K}$ & - & 137 & 600 & 0.5 \\
\hline 2 & 11-BTA & $293 \mathrm{~K}$ & 16.1 & 137 & 600 & -50.4 \\
\hline 3 & 12-BTA & $293 \mathrm{~K}$ & - & 137 & 600 & -2 \\
\hline 4 & 12-BTA & $293 \mathrm{~K}$ & 16.1 & 137 & 600 & -66.5 \\
\hline 5 & I1-BTA & $200 \mathrm{~K}$ & - & 137 & 600 & -10.8 \\
\hline 6 & I1-BTA & $200 \mathrm{~K}$ & 16.1 & 137 & 600 & -79.6 \\
\hline 7 & 12-BTA & $200 \mathrm{~K}$ & - & 137 & 600 & -2.5 \\
\hline 8 & 12-BTA & $200 \mathrm{~K}$ & 16.1 & 137 & 600 & -89.5 \\
\hline 9 & 12-BTA & $200 \mathrm{~K}$ & 16.1 & 137 & $600^{(a)}$ & $90.6^{(b)}$ \\
\hline 10 & 12-BTA & $200 \mathrm{~K}$ & 16.1 & 274 & $300^{(a)}$ & 86.0 \\
\hline 11 & 12-BTA & $200 \mathrm{~K}$ & 16.1 & 548 & $150^{(a)}$ & 82.9 \\
\hline 12 & 12-BTA & $200 \mathrm{~K}$ & 16.1 & 1096 & $75^{(\mathrm{a})}$ & 73.8 \\
\hline
\end{tabular}

Table S8. Optimization of S\&S-type catalytic experiments: composition and catalytic result for each mixture.

Catalytic loading in $\mathbf{c - B T A}=[\mathbf{c - B T A}] /[$ NPnone $]$. Conversion $>99 \%$ was obtained for all catalytic experiments. The optical purity of NPnol was determined by GC analysis, e.e. are set as positive and negative when $(S)$-NPnol and $(R)$-NPnol are the major enantiomers, respectively. (a) (R)-BTA was used instead of (S)-BTA. (b) A reaction performed on $112 \mathrm{mg}(0.68 \mathrm{mmol})$ of NPnone yielded the same e.e. and an isolated yield of $46 \%$.

Catalytic experiments aimed at probing the dynamic nature of the S\&S-type catalytic system (Figure 5): a tube was loaded with $\left[\mathrm{Cu}(\mathrm{OAc})_{2} \cdot \mathrm{H}_{2} \mathrm{O}\right](0.5 \mathrm{mg}, 2.55 \mu \mathrm{mol}, 3.0 \mathrm{~mol} \%)$ and 11BTA $(6.9 \mathrm{mg}, 10.0 \mu \mathrm{mol}, 12.0 \mathrm{~mol} \%)$ in dry THF $(500 \mu \mathrm{L})$ and the mixture was stirred for 30 minutes. The solvent was removed under vacuum and the tube was further put under vacuum $\left(10^{-3} \mathrm{mbar}\right)$ for 1 hour. Then 1-(4-nitrophenyl)ethanone (14.0 $\left.\mathrm{mg}, 0.085 \mathrm{mmol}, 100 \mathrm{~mol} \%\right)$ was added before flushing the tube with argon for 10 seconds. 
Then $43.4 \mathrm{mg}$ of a $1.0 \mathrm{mM}$ stock solution of $(\boldsymbol{S})$-BTA $(0.05 \mu \mathrm{mol}, 80 \mu \mathrm{M})$ was added to the tube as well as dry toluene. The total solvent volume was set equal to $500 \mu \mathrm{L}$. The mixture was stirred for $15 \mathrm{~min}$ at room temperature and then a-BTA $(10.9 \mathrm{mg}, 10.0 \mu \mathrm{mol}, 12.0 \mathrm{~mol} \%)$ in $100 \mu \mathrm{L}$ of toluene was added at time 0 . After a given time $(t), \mathrm{PhSiH}_{3}(21.0 \mu \mathrm{L}, 0.17 \mathrm{mmol}$, $200 \mathrm{~mol} \%$ ) was added. The reaction mixture was stirred for 12 hours before being hydrolyzed with aqueous $\mathrm{HCl}$ and analyzed by ${ }^{1} \mathrm{H}$ NMR and chiral GC.

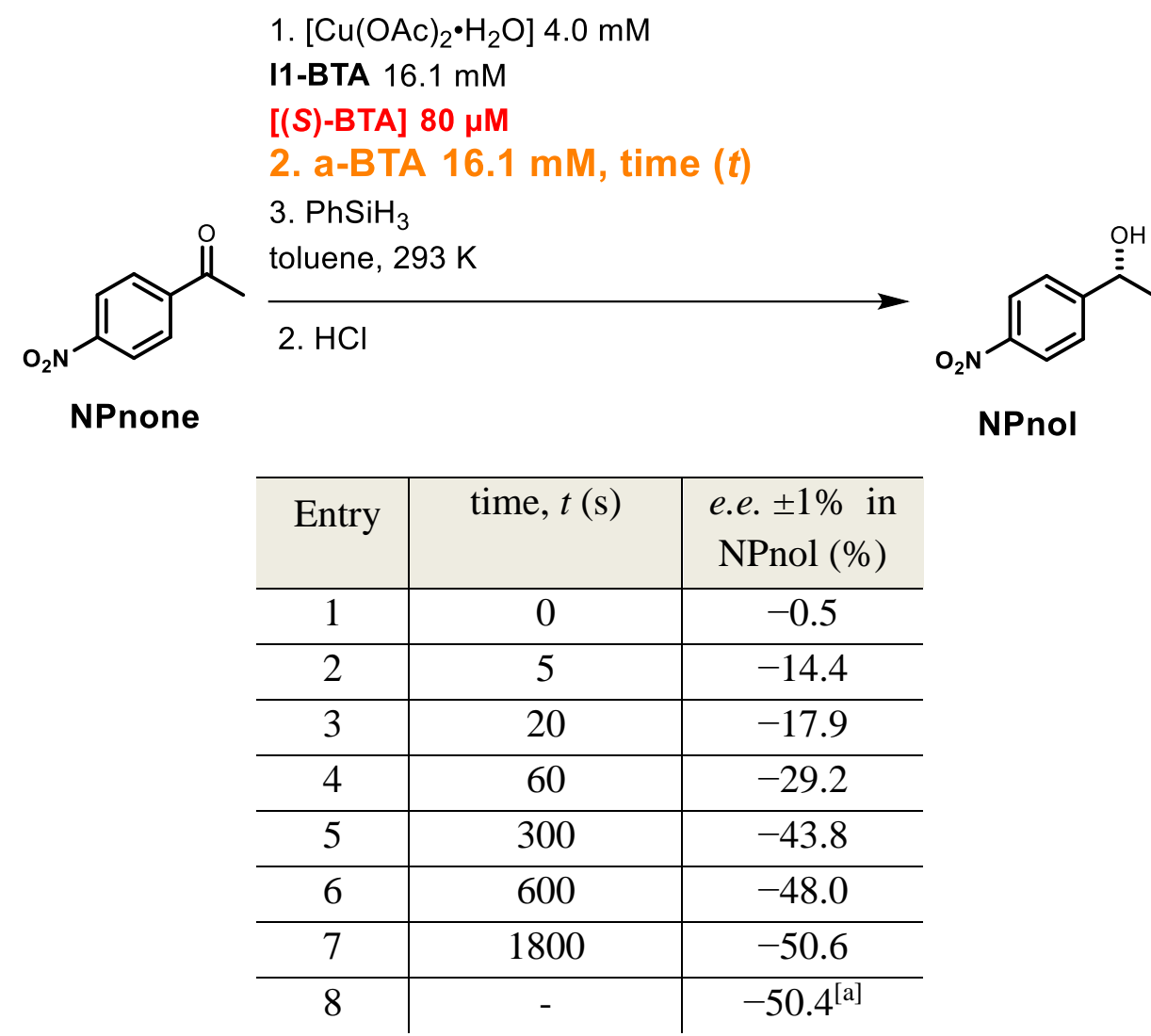

Table S9. Catalytic experiments aimed at probing the dynamic nature of the S\&S-type catalytic system (Figure 5).

Conversion $>99 \%$ was obtained for all catalytic experiments. The optical purity of NPnol was determined by GC analysis, e.e. are set as positive and negative when $(S)$-NPnol and $(R)$-NPnol are the major enantiomers, respectively. [a] Enantioselectivity obtained when all components are mixed together at room temperature then briefly heated to reflux and cooled down to $293 \mathrm{~K}$ prior to addition of $\mathrm{PhSiH}_{3}$. 


\section{Selected chiral GC analyses}

Table 2, Entry 1 and Table S6, Entry 2

I1-BTA, $(\boldsymbol{S})$-BTA $(0.06 \mathrm{~mol} \%), \mathrm{f}_{(S)-\mathrm{BTA}}=0.5 \%, 293 \mathrm{~K}$, no a-BTA $0.5 \%$ e.e.

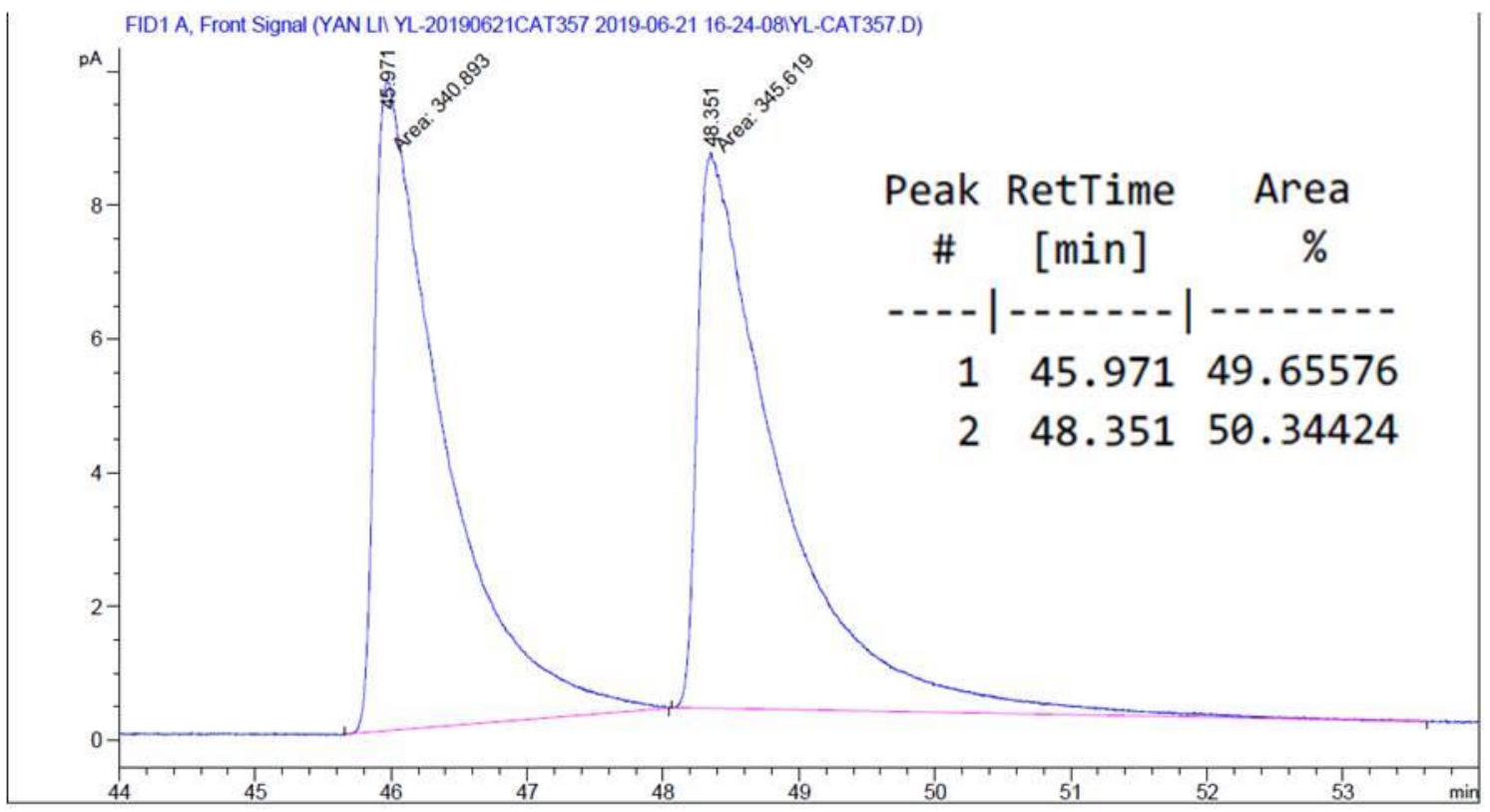

Table 2, Entry 2 and Table S6, Entry 9

I1-BTA, $(\boldsymbol{S})$-BTA $(0.06 \mathrm{~mol} \%), \mathrm{f}_{(S)-\mathrm{BTA}}=0.25 \%, 293 \mathrm{~K}$, with a-BTA $-50.4 \%$ e.e. $(R)$

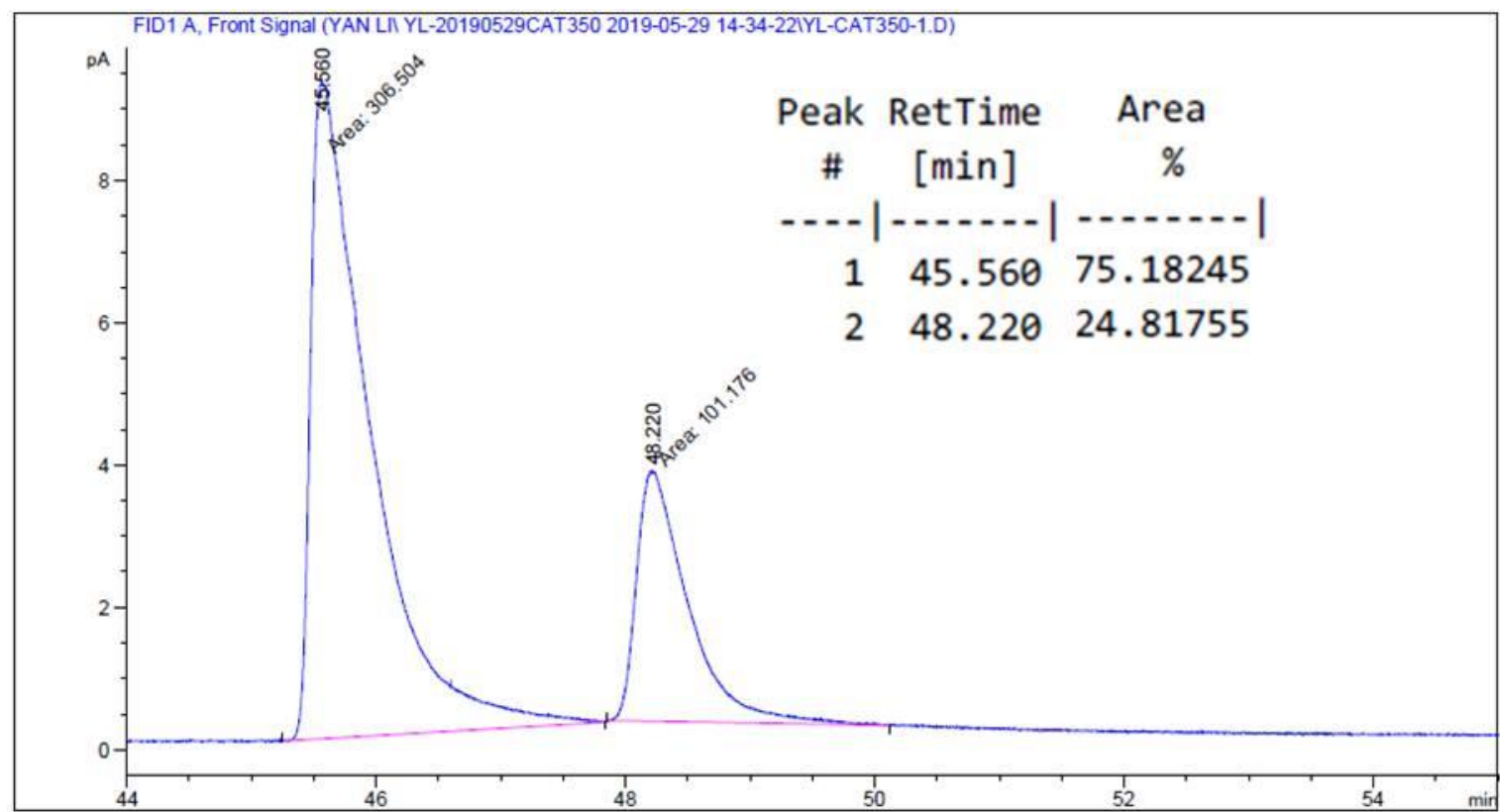


Table S7, Entry 10

I1-BTA, c-BTA ( $20 \%$ e.e. $), 293 \mathrm{~K}$, no a-BTA

$-28.8 \%$ e.e. $(R)$

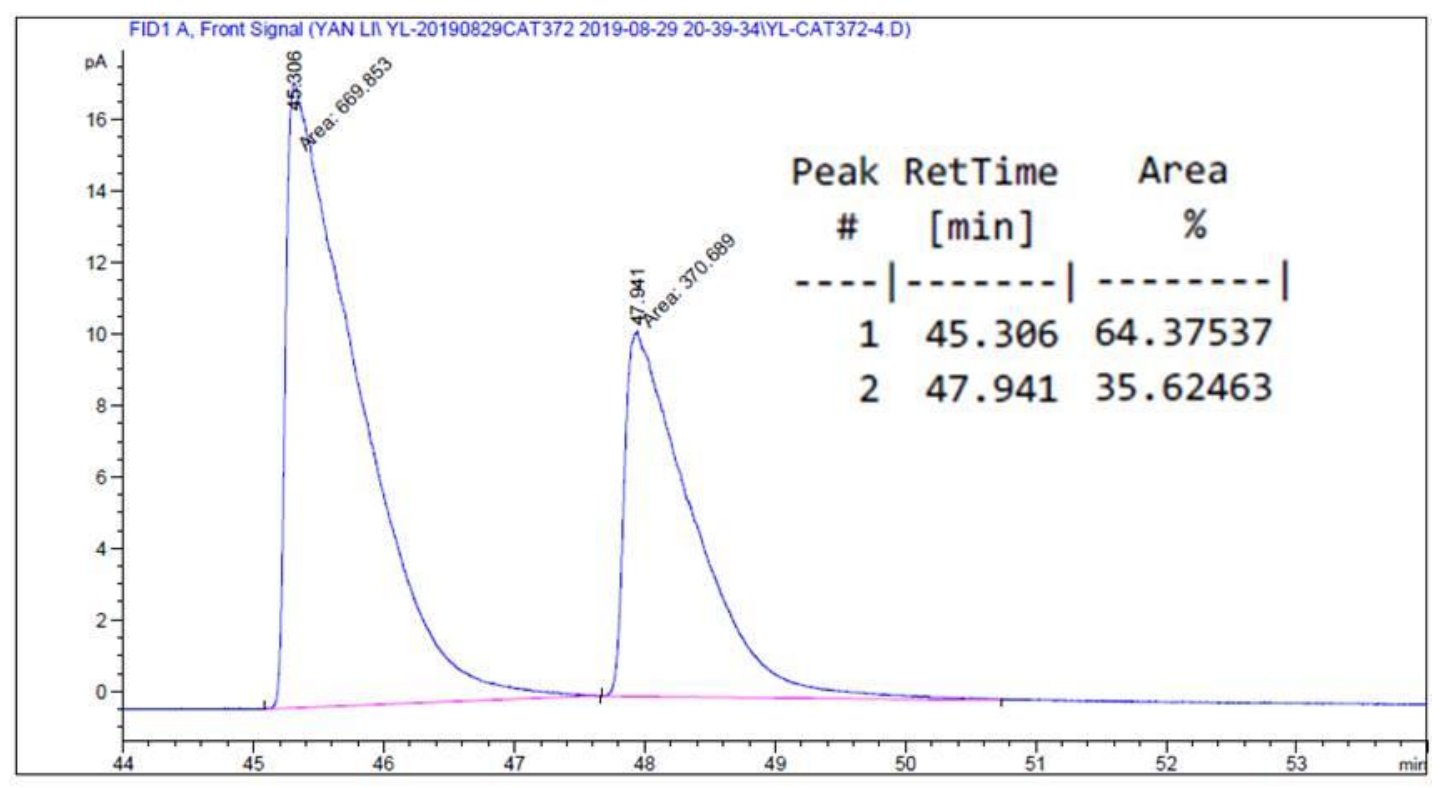

Table S7, Entry 23

I1-BTA, c-BTA ( $20 \%$ e.e. $), 293 \mathrm{~K}$, with a-BTA

$-51.0 \%$ e.e. $(R)$

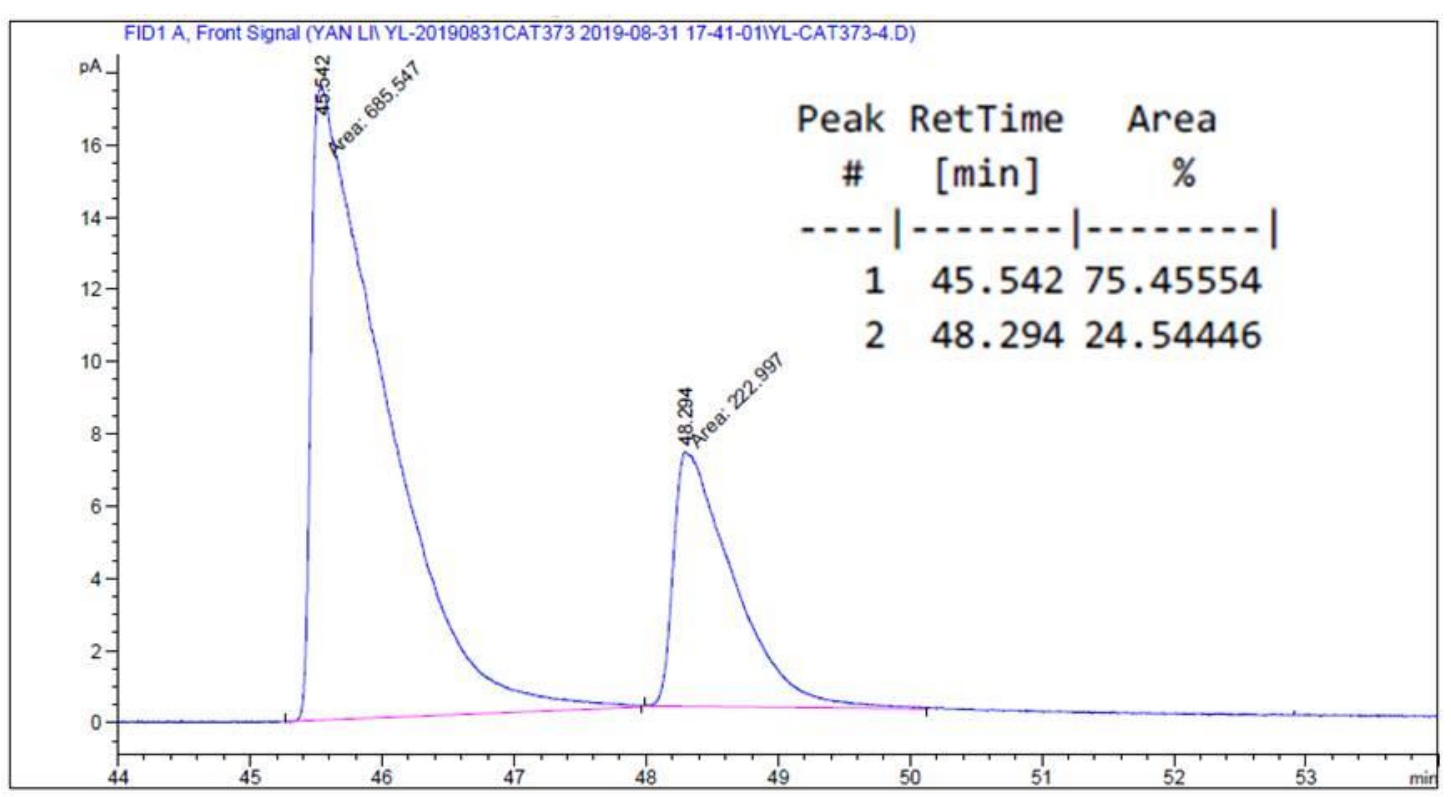


Table 2, Entry 4 and Table S8, Entry 7

I2-BTA, $(\boldsymbol{S})$-BTA $(0.06 \mathrm{~mol} \%), \mathrm{f}_{(S)-\mathrm{BTA}}=0.5 \%, 200 \mathrm{~K}$, no a-BTA $-2.5 \%$ e.e. $(R)$

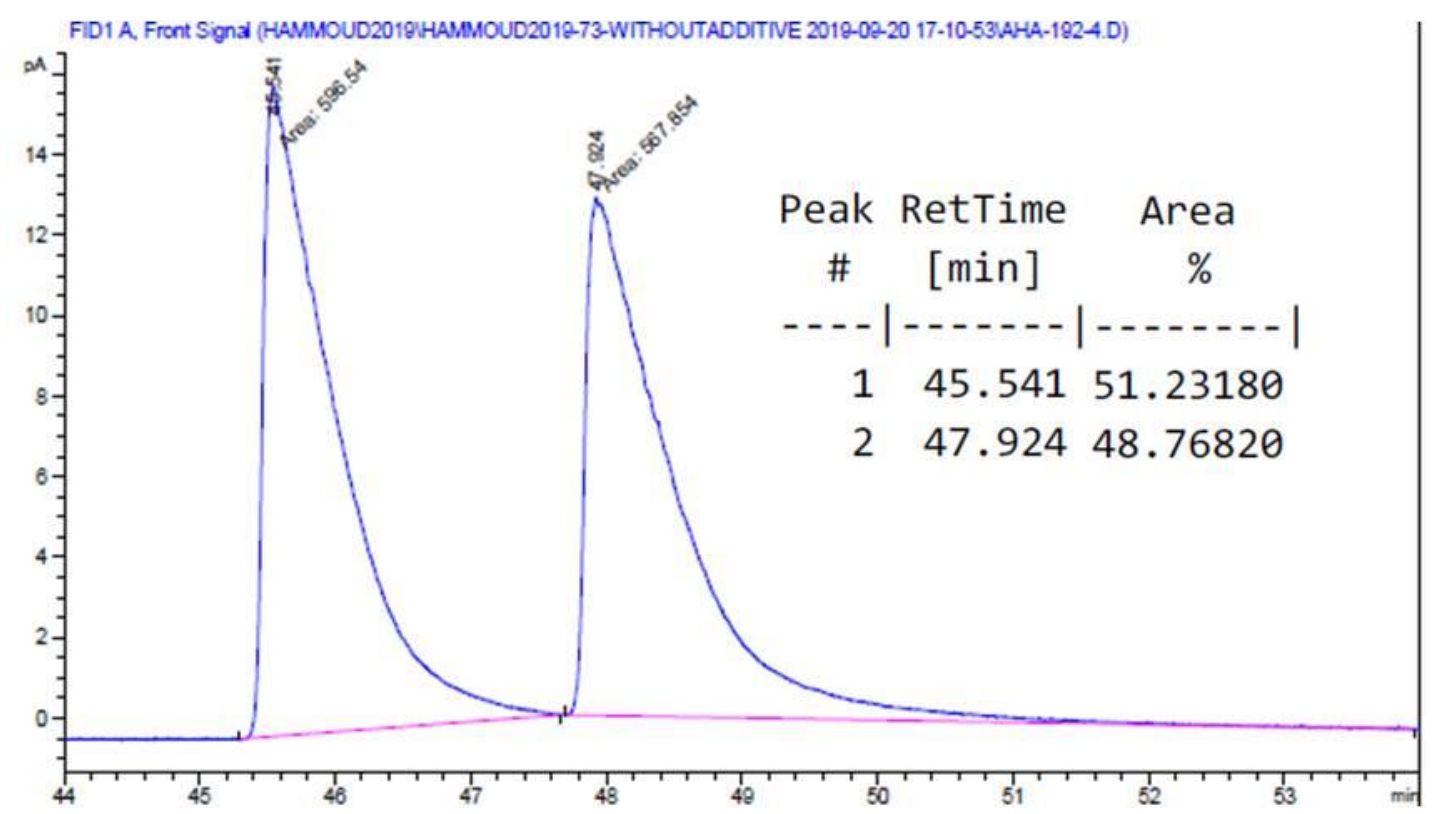

Table 2, Entry 5 and Table S8, Entry 8

12-BTA, $(\boldsymbol{S})$-BTA $(0.06 \mathrm{~mol} \%), \mathrm{f}_{(S)-\mathrm{BTA}}=0.25 \%, 200 \mathrm{~K}$, with a-BTA $-89.5 \%$ e.e. $(R)$

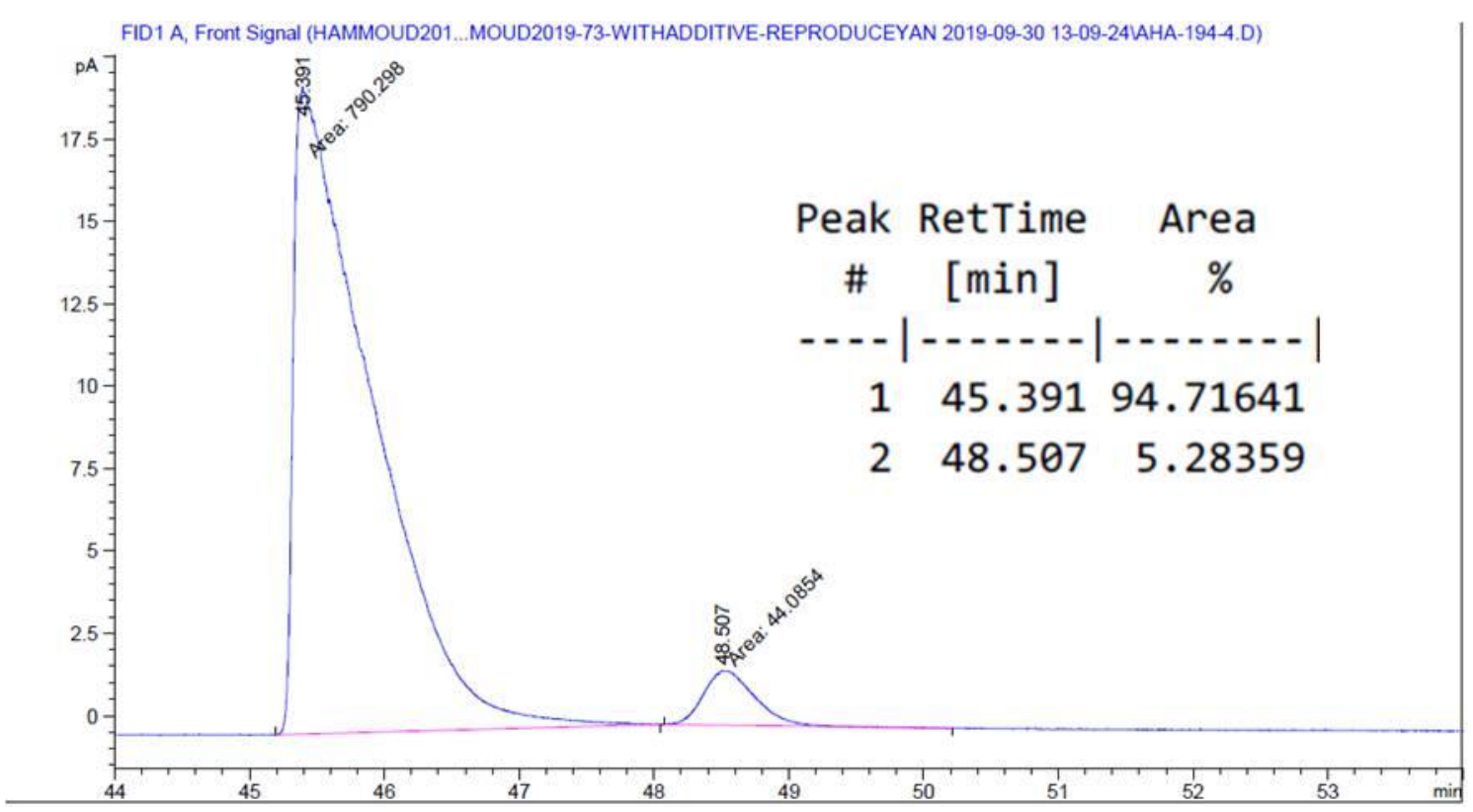


Table 2, Entry 6 and Table S8, Entry 9

12-BTA, $(\boldsymbol{R})$-BTA $(0.06 \mathrm{~mol} \%), \mathrm{f}_{(R)-\mathrm{BTA}}=0.25 \%, 200 \mathrm{~K}$, with a-BTA

$90.6 \%$ e.e. $(S)$

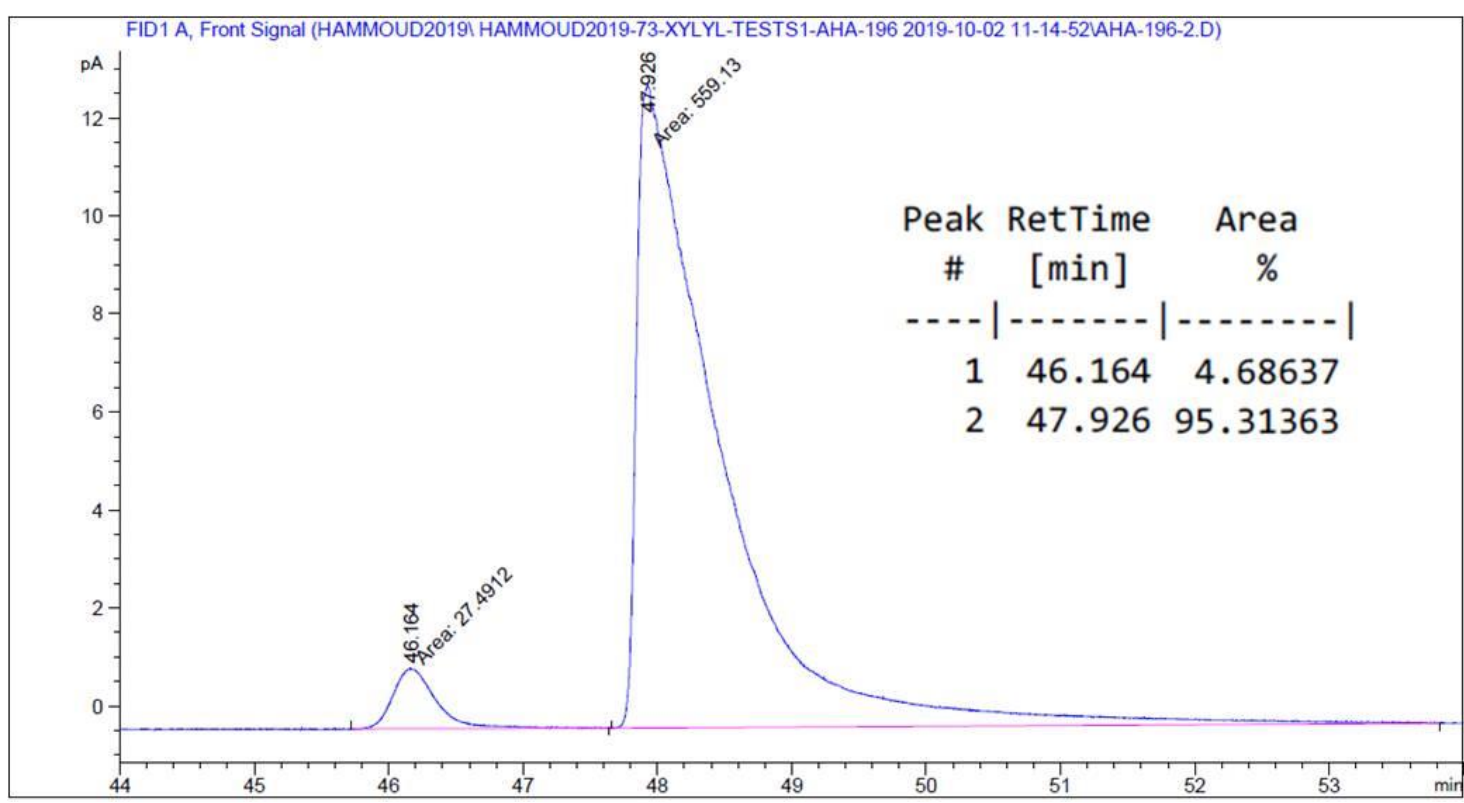

Table 2, Entry 7 and Table S8, Entry 12

12-BTA, $(\boldsymbol{R})$-BTA $(75 \mathrm{ppm}), \mathrm{f}_{(R)-\mathrm{BTA}}=0.25 \%, 200 \mathrm{~K}$, with a-BTA

$73.8 \%$ e.e. $(S)$

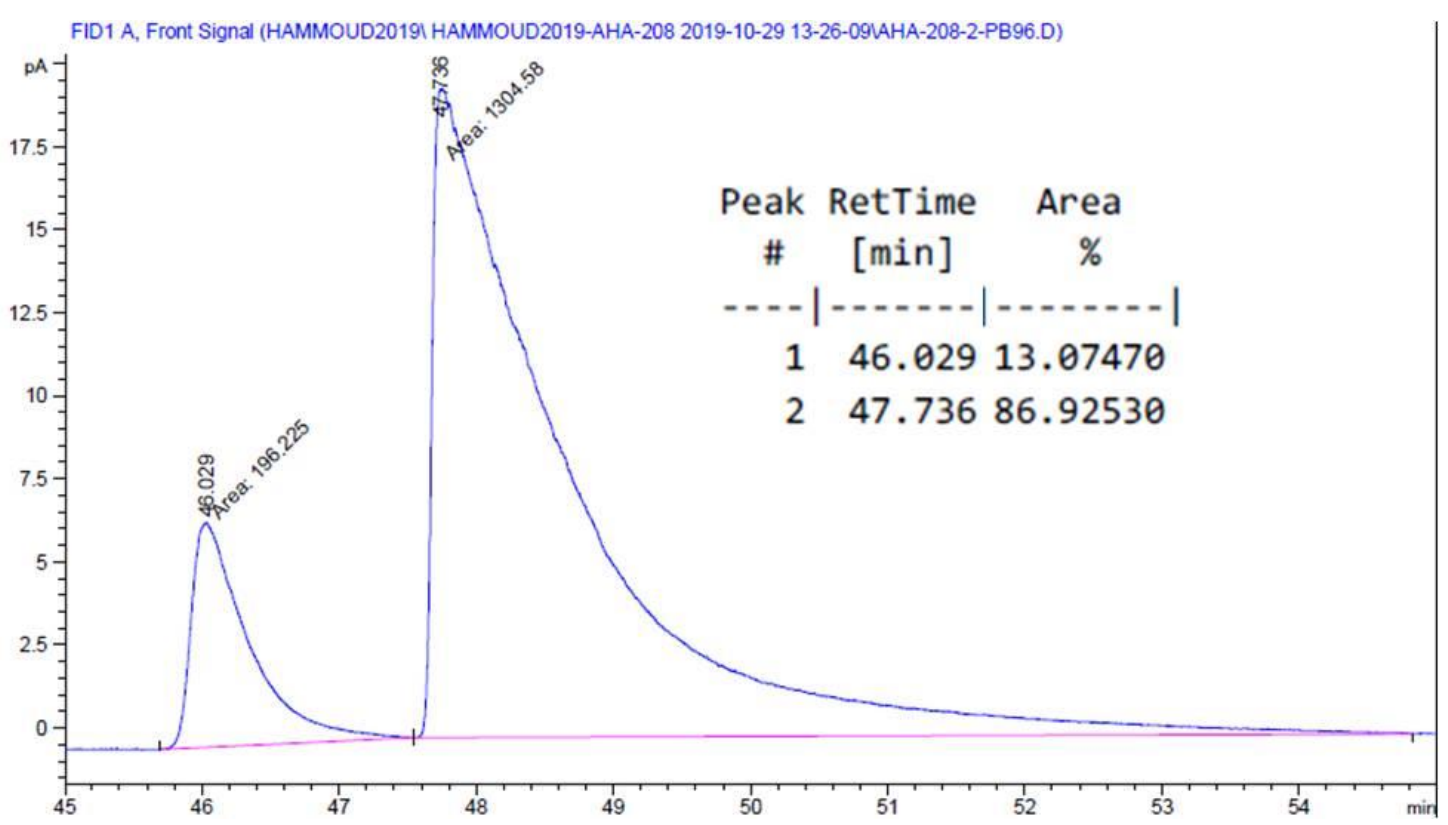


Synthetic procedures

Materials preparation and methods: The synthesis and characterization of 11-BTA, ${ }^{1} 3,5-$ bisoctylaminocarbonyl-benzoic acid $^{6}(\boldsymbol{S})$-BTA ${ }^{2 \mathrm{c}}$ and $(\boldsymbol{R})-\mathbf{B T A}^{2 \mathrm{c}}$ have been described previously. ( $\boldsymbol{S})$-BTA and $(\boldsymbol{R})$-BTA monomers used in this study have been purified by preparative HPLC. 1-Aminocyclohexanecarboxylic acid, bis(3,5dimethylphenyl)chlorophosphine and 4-bromo- $N, N$-bis(trimethylsilyl)aniline were purchased from Sigma-Aldrich and used as received. Benzene-1,3,5-tricarbonyl chloride, 1-(4nitrophenyl)ethanone (>98\%), $\mathrm{PhSiH}_{3}(>97 \%)$ and $\left[\mathrm{Cu}(\mathrm{OAc})_{2} \cdot \mathrm{H}_{2} \mathrm{O}\right](>99 \%)$ were purchased from Alfa Aesar. 1-dodecanol, DMAP and $p-\mathrm{TsOH} \cdot \mathrm{H}_{2} \mathrm{O}$ were acquired from Sigma Aldrich and were used directly. EDC. $\mathrm{HCl}$ was purchased from Fluorochem. Dried solvents were obtained from an SPS solvent purification system (IT-Inc). NMR spectra were recorded on a Bruker Avance 300 spectrometer and calibrated to the residual solvent peak: DMSO- $\mathrm{d}_{6}\left({ }^{1} \mathrm{H}\right.$ : $\left.2.50 \mathrm{ppm} ;{ }^{13} \mathrm{C}: 39.52 \mathrm{ppm}\right) ; \mathrm{CDCl}_{3}\left({ }^{1} \mathrm{H}: 7.26 \mathrm{ppm} ;{ }^{13} \mathrm{C}: 77.16 \mathrm{ppm}\right)$. Acetone- $\mathrm{d}_{6}\left({ }^{1} \mathrm{H}: 2.05\right.$ ppm; ${ }^{13} \mathrm{C}: 29.84 \mathrm{ppm}$ ). Peaks are reported with their corresponding multiplicity (s: singlet; br $\mathrm{s}$ : broad singlet, d: doublet, t: triplet; q: quartet) and integration, and respective $J$ coupling constants are given in Hertz. Exact mass measurements (HRMS) were obtained on TQ R3010 HRMS spectrometer by ESI+ ionization and are reported in $\mathrm{m} / \mathrm{z}$ for the major signal. FTIR spectra for solids were recorded by reflection on a Ge probe (attenuated total reflectance (ATR) and the main bands were reported (w: weak, m: medium, s: strong, br: broad).

\section{Synthesis of a-BTA:}

\section{Step 1: Synthesis of dodecyl ester $p$-TsOH salt of 1-aminocyclohexanecarboxylic acid:}

In a Dean-Stark apparatus-mounted one-neck flask, 1-aminocyclohexanecarboxylic acid (1.0 $\mathrm{g}, 7.0 \mathrm{mmol}, 1.0$ equiv.) is suspended in toluene $(0.047 \mathrm{M}, 150 \mathrm{~mL})$, and $p-\mathrm{TsOH} \cdot \mathrm{H}_{2} \mathrm{O}(1.6 \mathrm{~g}$, $8.4 \mathrm{mmol}, 1.2$ equiv.) is added at room temperature. Dodecanol $(1.43 \mathrm{~g}, 7.7 \mathrm{mmol}, 1.1$ equiv.) is then added, and the resulting slurry is stirred at reflux temperature until the mixture turns totally clear. After cooling the reaction mixture to room temperature, the crude reaction mixture is evaporated under reduced pressure to give a thick oil or a solid. This residue is taken up in $c a .70 \mathrm{~mL}$ of $\mathrm{Et}_{2} \mathrm{O}$, gently heated to $35^{\circ} \mathrm{C}$, and let cool in an ice bath. The resulting precipitate is filtered under vacuum and washed with cold $\mathrm{Et}_{2} \mathrm{O}$ to remove residual reactants. The white solid is then dried under vacuum to yield the dodecyl ester $p$-TsOH salt of 1-aminocyclohexanecarboxylic acid (3.38 g, $6.3 \mathrm{mmol}, 90 \%$ yield). ${ }^{1} \mathrm{H}$ NMR (400 MHz, DMSO-d $\left._{6}\right) \delta(\mathrm{ppm}) 8.37(\mathrm{~s}, 3 \mathrm{H}), 7.48\left(\mathrm{~d},{ }^{3} \mathrm{~J}=7.7 \mathrm{~Hz}, 2 \mathrm{H}\right), 7.11\left(\mathrm{~d},{ }^{3} \mathrm{~J}=7.8 \mathrm{~Hz}, 2 \mathrm{H}\right), 4.18(\mathrm{t}$, $\left.{ }^{3} J=6.5 \mathrm{~Hz}, 2 \mathrm{H}\right), 2.29$ (s, 3H), 2.03-1.90 (m, 2H), 1.80-1.52 (m, 8H), 1.47-1.18 (m, 20H), 0.87 $\left(\mathrm{t},{ }^{3} J=6.9 \mathrm{~Hz}, 3 \mathrm{H}\right) .{ }^{13} \mathrm{C}\left\{{ }^{1} \mathrm{H}\right\}$ NMR (101 MHz, DMSO-d 6$) \delta(\mathrm{ppm}) 170.93,145.59,137.59$, $128.00,125.45,65.94,58.65,31.23,28.50,27.85,23.80,22.06,20.74,20.22$, 13.92. HRMS (ESI, $m / z)$ : Calculated for $\mathrm{C}_{19} \mathrm{H}_{38} \mathrm{NO}_{2}$, [M-OTs] $]^{+}: 312.2897$, found: 312.2896 .

\section{Step 2: Synthesis of a-BTA:}

In a flame-dried round-bottom flask, benzene-1,3,5-tricarbonyl chloride ( $0.8 \mathrm{~g}, 3.0 \mathrm{mmol}, 1.0$ equiv.) was dissolved in dry $\mathrm{CH}_{2} \mathrm{Cl}_{2}(100 \mathrm{~mL})$ at room temperature under argon atmosphere. The dodecyl ester $p$-TsOH salt of 1-aminocyclohexanecarboxylic acid (5.02 g, 9.9 mmol, 3.3 
equiv.) was then added in one portion, and the resulting mixture was cooled to $0^{\circ} \mathrm{C}$ with an ice/water bath. Dry Et $3 \mathrm{~N}$ ( $2.8 \mathrm{~mL}, 19.8 \mathrm{mmol}, 6.6$ equiv.) was then added dropwise, the reaction was let warmed to room temperature and stirred for $36 \mathrm{~h}$. Brine was then added to the flask, and the crude mixture was extracted thrice with $\mathrm{CH}_{2} \mathrm{Cl}_{2}$. The combined organic phases were dried over $\mathrm{MgSO}_{4}$, filtered, and the solvent was evaporated under reduced pressure. The product was then purified by flash column chromatography on silica gel, eluting with DCM/AcOEt 100:0-85:15 gradient yielding a-BTA as an off-white gum (1.31 g, $1.2 \mathrm{mmol}$, $40 \%$ yield). ${ }^{1} \mathrm{H}$ NMR (acetone- $\left.\mathrm{d}_{6}\right): \delta(\mathrm{ppm}) 8.39(\mathrm{~s}, 3 \mathrm{H}), 7.98(\mathrm{~s}, 3 \mathrm{H}), 4.07$ (t, ${ }^{3} \mathrm{~J}=6.5 \mathrm{~Hz}$, $6 \mathrm{H}), 2.30-2.15(\mathrm{~m}, 6 \mathrm{H}), 2.01-1.91(\mathrm{~m}, 4 \mathrm{H}), 1.79-1.55(\mathrm{~m}, 20 \mathrm{H}), 1.46-1.10(\mathrm{~m}, 60 \mathrm{H}), 0.87$ (t, $\left.{ }^{3} J=7.0 \mathrm{~Hz}, 9 \mathrm{H}\right) .{ }^{13} \mathrm{C}\left\{{ }^{1} \mathrm{H}\right\}$ NMR (acetone-d 6 ): $\delta$ (ppm) 174.48, 166.45, 136.13, 129.80, 65.22, 60.35, 33.28, 32.67, 26.72, 26.23, 23.36, 22.50, 14.38. HRMS (ESI, $m / z)$ : Calculated for $\mathrm{C}_{66} \mathrm{H}_{111} \mathrm{~N}_{3} \mathrm{O} 9 \mathrm{Na},[\mathrm{M}+\mathrm{Na}]^{+}:$1112.8213, found: 1112.8224. FT-IR (ATR, $\mathrm{cm}^{-1}$ ): $606(\mathrm{~m}), 680$ (m), 1139 (s), 1202 (s), 1295 (m), 1370 (w), 1451 (m), 1551 (s), 1632 (s), 1732 (s), 2848 (s), 2923 (s), 3054 (w), 3228 (br).

\section{$\underline{\text { Synthesis of 12-BTA: }}$}<smiles>Cc1cc(C)cc(P(Cl)c2cc(C)cc(C)c2)c1</smiles>

(i) $\mathrm{Mg}$

(ii) toluene, $0^{\circ} \mathrm{C}$ then reflux

(iii) $\mathrm{MeOH}$, reflux

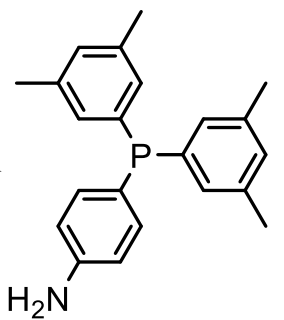

\section{Step 1: synthesis of 4-\{bis-(3,5-dimethyl-phenyl)phosphine\}-aniline:}

In a three-neck round-bottom flask equipped with a condenser under argon, 4-bromo- $N, N$ bis(trimethylsilyl)aniline (5.0 g, $15.8 \mathrm{mmol}, 1.0$ equiv.) in THF (16 mL) was added over 40 minutes to a well-stirred dispersion of magnesium turnings ( $0.46 \mathrm{~g}, 19.0 \mathrm{mmol}, 1.2$ equiv.) in THF (just enough to cover the magnesium turnings). Prior to starting the addition, magnesium turnings were activated with a small crystal of $\mathrm{I}_{2}$ and a drop of 4-bromo- $\mathrm{N}, \mathrm{N}$ bis(trimethylsilyl)aniline. The reaction was stirred first at room temperature, then heated to $60^{\circ} \mathrm{C}$ for 3 hours. Bis(3,5-dimethylphenyl)chlorophosphine $(5.0 \mathrm{~g}, 18.1 \mathrm{mmol}, 1.15$ equiv. $)$ in toluene $(7.4 \mathrm{~mL})$ was added over 15 minutes to the in situ generated toluene solution of 4$(N, N \text {-trimethylsilyl })_{2}$-aniline magnesium bromide while the reaction flask was cooled with in an ice bath. The reaction mixture was stirred for 30 minutes. The progress of the reaction was probed by ${ }^{31} \mathrm{P}\left\{{ }^{1} \mathrm{H}\right\}$ NMR. The volatiles were removed under vacuum and the solid residue was extracted with dry $\mathrm{Et}_{2} \mathrm{O}$ via a cannula to another three-neck round-bottom flask equipped with a special fritted funnel designed to perform filtrations under argon. $\mathrm{Et}_{2} \mathrm{O}$ was removed under vacuum, the crude product was then dissolved in $\mathrm{MeOH}(22 \mathrm{~mL})$ and the solution was stirred at reflux temperature for one day under argon. The solution was evaporated under vacuum, and the crude product was purified by flash column chromatography on silica gel, eluting with DCM/methanol 99:1-95:5 gradient yielding 4-\{bis-(3,5-dimethylphenyl)phosphine $\}$-aniline $(3.17 \mathrm{~g}, 9.5 \mathrm{mmol}, 60 \%$ yield $)$ as a yellow oil. ${ }^{1} \mathrm{H} \mathrm{NMR}\left(\mathrm{CDCl}_{3}\right): \delta$ (ppm) $7.17\left(\mathrm{t},{ }^{3} \mathrm{~J}=8.0 \mathrm{~Hz}, 2 \mathrm{H}\right), 6.95(\mathrm{~s}, 4 \mathrm{H}), 6.92(\mathrm{~s}, 2 \mathrm{H}), 6.66\left(\mathrm{~d},{ }^{3} \mathrm{~J}=7.9 \mathrm{~Hz}, 2 \mathrm{H}\right), 3.75$ (br s, 
2H), 2.27 (s, 12H). ${ }^{31} \mathrm{P}\left\{{ }^{1} \mathrm{H}\right\} \quad \mathrm{NMR}\left(\mathrm{CDCl}_{3}\right): \delta(\mathrm{ppm})-6.48 .{ }^{13} \mathrm{C}\left\{{ }^{1} \mathrm{H}\right\}\left(\mathrm{CDCl}_{3}\right): \delta(\mathrm{ppm})$ 147.16, 138.1 (d, $J=9.9 \mathrm{~Hz}), 137.8$ (d, $J=7.1 \mathrm{~Hz}), 135.7$ (d, $J=21.4 \mathrm{~Hz}), 131.2$ (d, $J=19.2$ $\mathrm{Hz}), 130.2,125.1(\mathrm{~d}, J=6.6 \mathrm{~Hz}), 115.2(\mathrm{~d}, J=8.2 \mathrm{~Hz}), 21.4$. HRMS (ESI, $m / z)$ : Calculated for $\mathrm{C}_{22} \mathrm{H}_{25} \mathrm{NP},[\mathrm{M}+\mathrm{H}]^{+}: 334.1720$, found: 334.1719 .

\section{Step 2: Synthesis of 12-BTA:}<smiles>CCNC(=O)c1cc(C(=O)O)cc(C(=O)NC=Cc2cc(C)cc(P(c3ccc(N)cc3)c3cc(C)cc(C)c3)c2)c1</smiles>

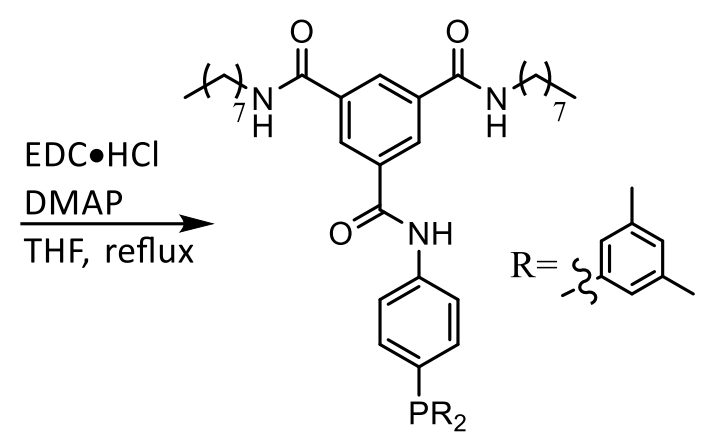

3,5-bisoctylaminocarbonyl-benzoic acid ${ }^{5}(1.0 \mathrm{~g} 2.5 \mathrm{mmol}, 1.0$ equiv.) was suspended in THF $(100 \mathrm{~mL})$ under argon and DMAP $(0.45 \mathrm{~g}, 3.8 \mathrm{mmol}, 1.5 \mathrm{equiv}),. \mathrm{EDC} \cdot \mathrm{HCl}(0.72 \mathrm{~g}, 3.8$ mmol, 1.5 equiv.) and 4-\{bis-(3,5-dimethyl-phenyl)phosphine $\}$-aniline (1.0 g $3.0 \mathrm{mmol}, 1.2$ equiv.) were added to the flask. The reaction mixture was stirred at reflux temperature for two days under argon. Then the reaction mixture was cooled to room temperature, and the solvent was evaporated under vacuum. DCM was added to the residue, and the organic layer was washed three times with water. Organic layers were combined, dried over magnesium sulfate and evaporated under vacuum. The crude product was purified by flash column chromatography on silica gel, eluting with DCM/AcOEt 95:5-88:12 gradient yielding 12-BTA (1.0 g, $1.4 \mathrm{mmol}, 55 \%$ yield) as a colourless solid. ${ }^{1} \mathrm{H}$ NMR (DMSO-d 6 ) $\delta(\mathrm{ppm}) 10.60$ (s, $1 \mathrm{H}), 8.69(\mathrm{t}, J=5.5 \mathrm{~Hz}, 2 \mathrm{H}), 8.49-8.47(\mathrm{~m}, 2 \mathrm{H}), 8.44-8.41(\mathrm{~m}, 1 \mathrm{H}), 7.82(\mathrm{~d}, J=8.1 \mathrm{~Hz}, 2 \mathrm{H})$, $7.27(\mathrm{t}, J=7.5 \mathrm{~Hz}, 2 \mathrm{H}), 7.01(\mathrm{~s}, 2 \mathrm{H}), 6.86(\mathrm{~d}, J=8.0 \mathrm{~Hz}, 4 \mathrm{H}), 3.28(\mathrm{q}, J=7.5 \mathrm{~Hz}, 4 \mathrm{H}), 2.22$ (s, 12H), 1.63-1.46 (m, 4H), 1.28-1.17 (m, 20H), 0.85 (t, $J=6.9 \mathrm{~Hz}, 6 \mathrm{H}) .{ }^{31} \mathrm{P}\left\{{ }^{1} \mathrm{H}\right\}$ NMR (DMSO$\left.\mathrm{d}_{6}\right) \delta(\mathrm{ppm})-7.42 .{ }^{13} \mathrm{C}\left\{{ }^{1} \mathrm{H}\right\} \mathrm{NMR}\left(\mathrm{DMSO}_{-} \mathrm{d}_{6}\right) \delta(\mathrm{ppm}) 165.18,165.01,139.63,137.53(\mathrm{~d}, J=$ $7.3 \mathrm{~Hz}), 136.83$ (d, $J=11.0 \mathrm{~Hz}), 135.2,133.99$ (d, $J=20.5 \mathrm{~Hz}), 131.43$ (d, J= 10.4 Hz), 130.77 (d, $J=19.7 \mathrm{~Hz}), 130.38,128.92,128.75,120.30$ (d, $J=7.3 \mathrm{~Hz}), 31.2,29.0,28.7,28.6,26.5$, 22.1, 20.9, 13.9. HRMS (ESI, $m / z$ ): Calculated for $\mathrm{C}_{47} \mathrm{H}_{63} \mathrm{~N}_{3} \mathrm{O}_{3} \mathrm{P},[\mathrm{M}+\mathrm{H}]^{+}:$748.4602, found: 748.4602. FT-IR (ATR, cm ${ }^{-1}$ ): 646 (m), 690 (s), 827 (m), 845 (m), 908 (w), 1093 (w), 1124 (w), $1186(\mathrm{w}), 1259$ (m), 1290 (s), 1317 (s), 1394 (w), 1464 (m), 1497 (m), 1525 (s), 1555 (m), 1591 (s), 1633 (s), 2855 (m), 2922 (s), 3026 (w), 3086 (w), 3252 (br). 


\section{NMR spectra}

Ammonium tosylate salt of 1-aminocyclohexanecarboxylic acid

${ }^{1} \mathrm{H}$ NMR (DMSO-d 6$)$

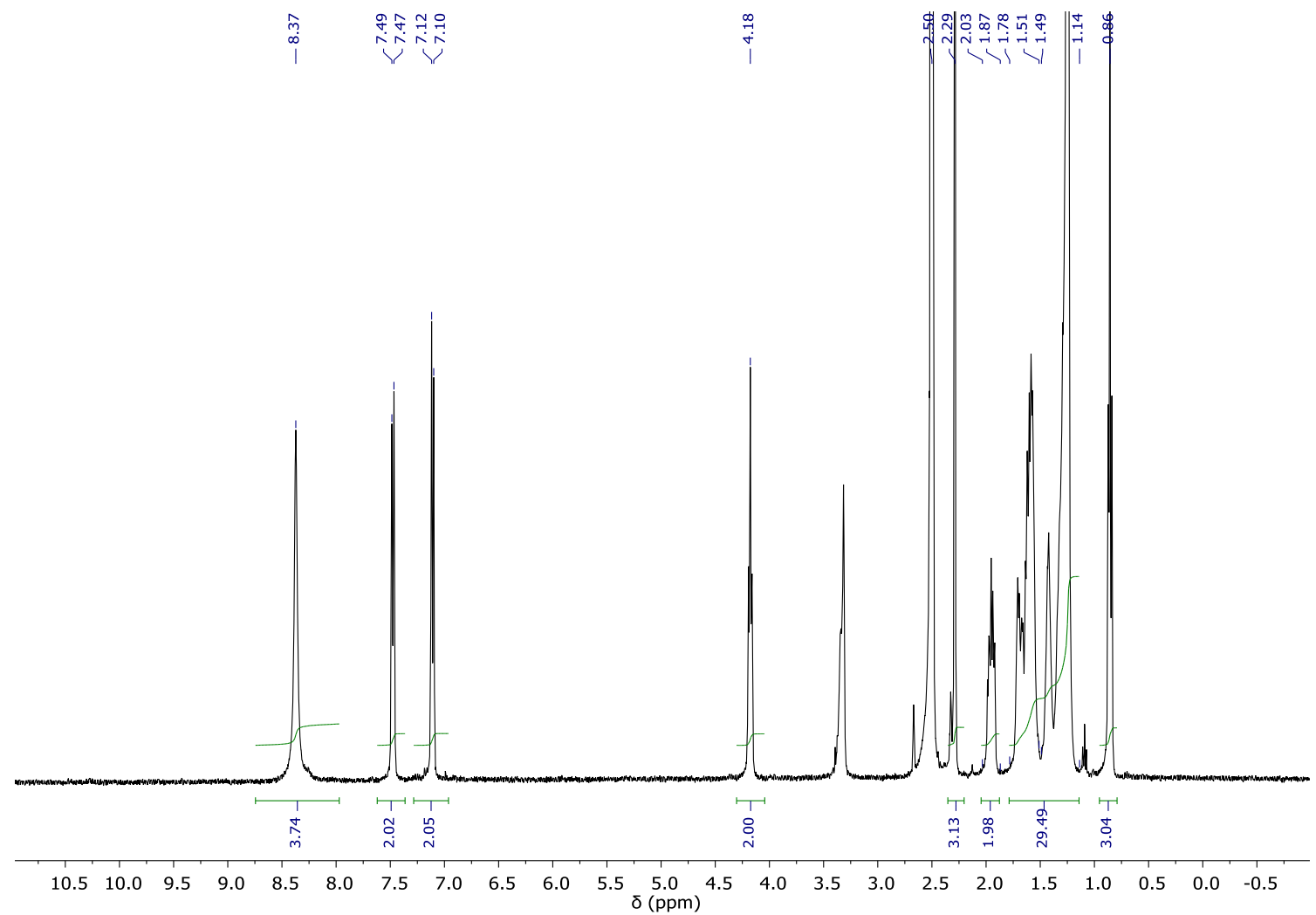

${ }^{13} \mathrm{C}\left\{{ }^{1} \mathrm{H}\right\}$ NMR (DMSO-d 6$)$

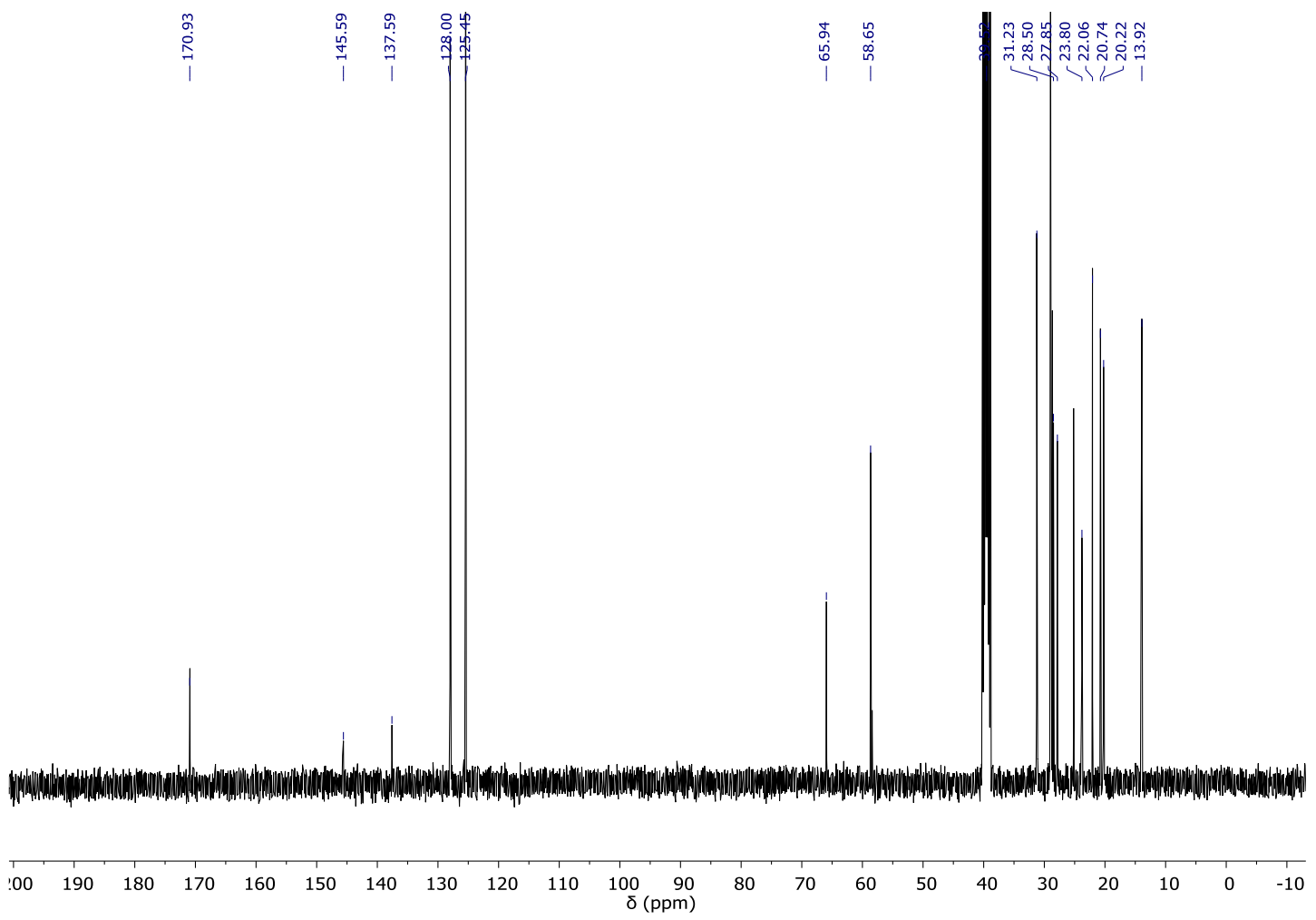




\section{a-BTA}

${ }^{1} \mathrm{H}$ NMR (acetone- $\mathrm{d}_{6}$ )

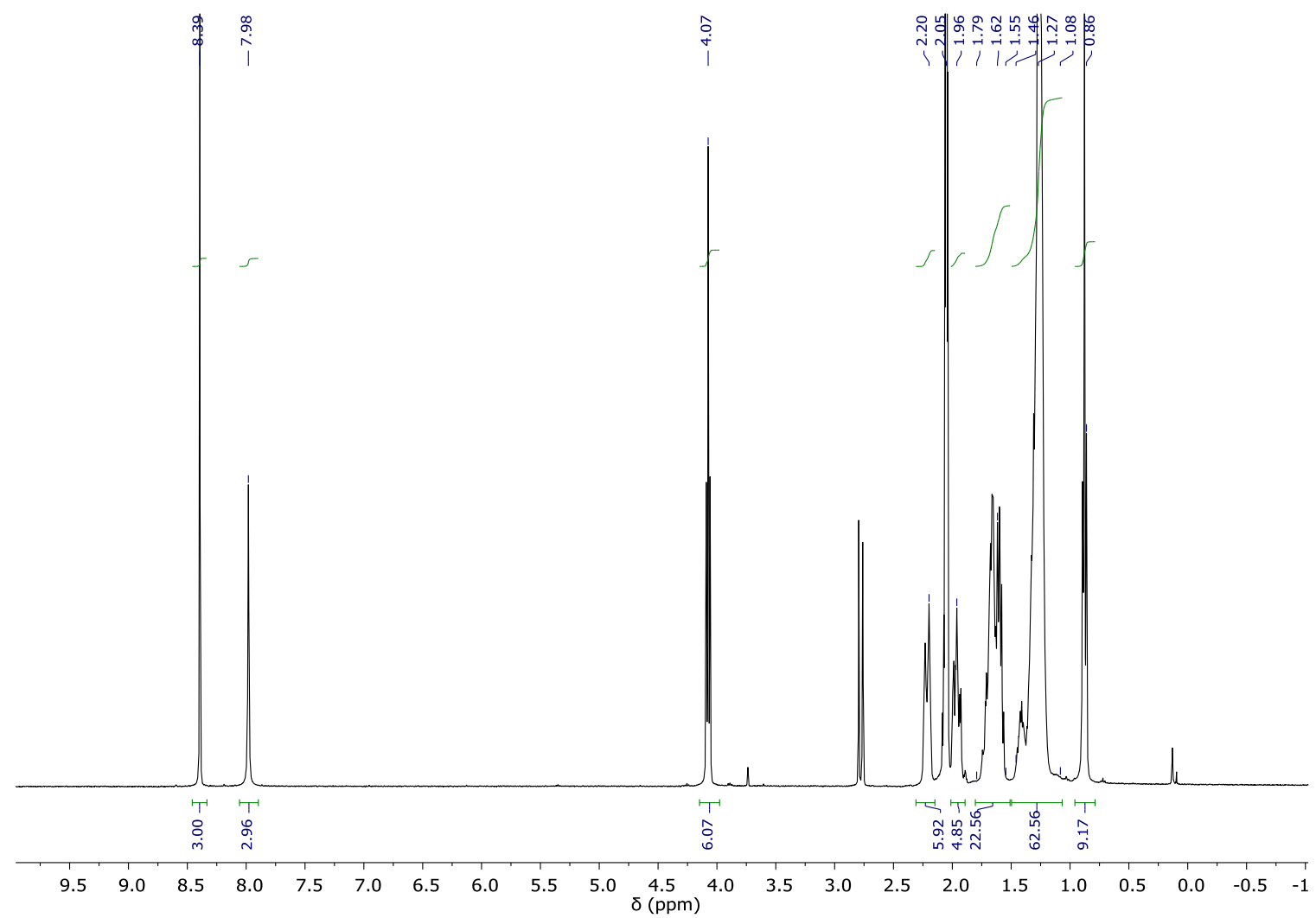

${ }^{13} \mathrm{C}\left\{{ }^{1} \mathrm{H}\right\}$ NMR (acetone- $\mathrm{d}_{6}$ )

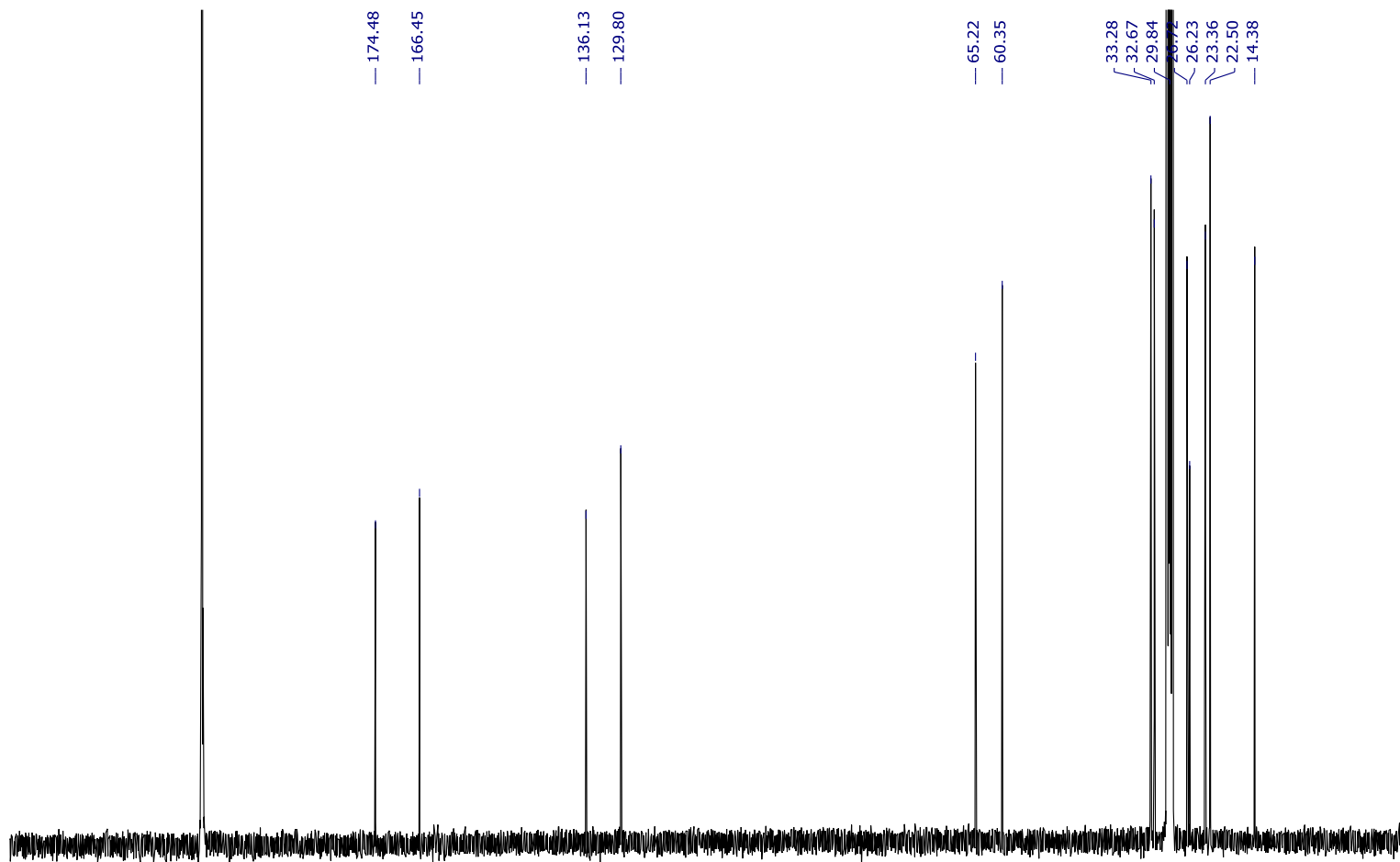

$\begin{array}{llllllllllllllllllllllllllll}40 & 230 & 220 & 210 & 200 & 190 & 180 & 170 & 160 & 150 & 140 & 130 & 120 & 110 & 100 & 90 & 80 & 70 & 60 & 50 & 40 & 30 & 20 & 10 & 0 & -1 C\end{array}$ 
${ }^{1} \mathrm{H} \mathrm{NMR}\left(\mathrm{CDCl}_{3}\right)$
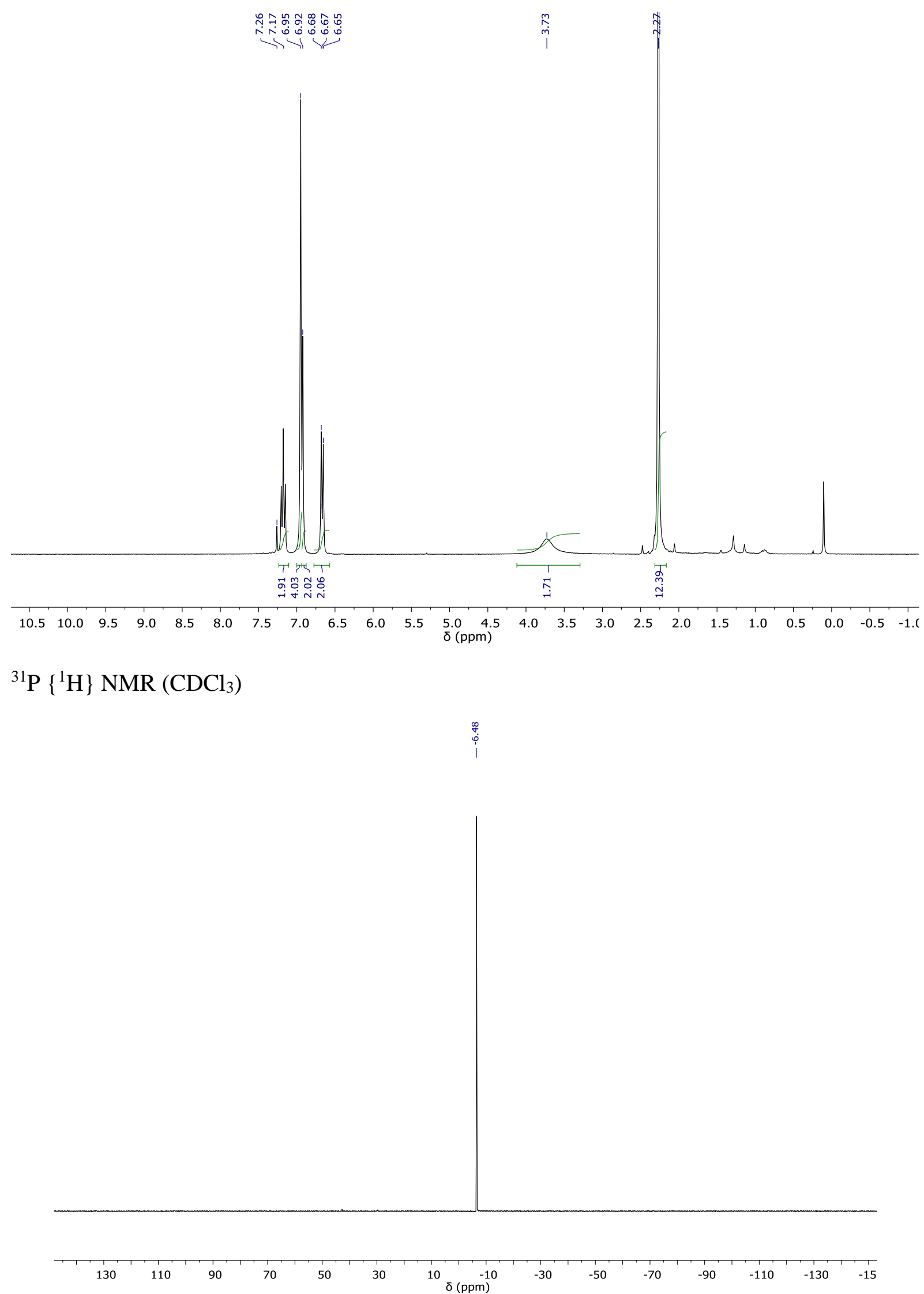
${ }^{13} \mathrm{C}\left\{{ }^{1} \mathrm{H}\right\}$ NMR $\left(\mathrm{CDCl}_{3}\right)$

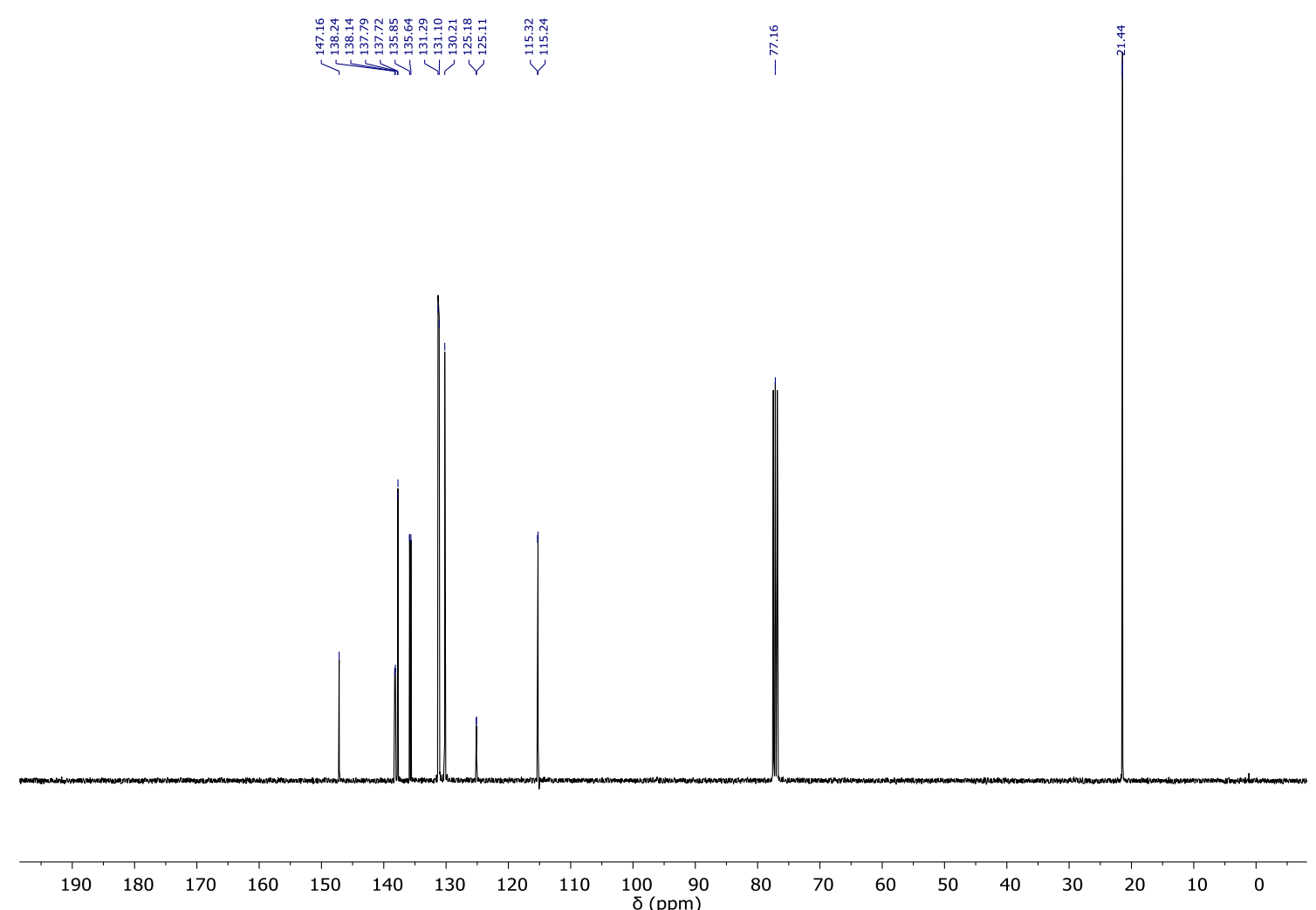




\section{2-BTA}

${ }^{1} \mathrm{H}$ NMR $\left(\mathrm{DMSO}-\mathrm{d}_{6}\right)-(*=$ residual AcOEt $)$

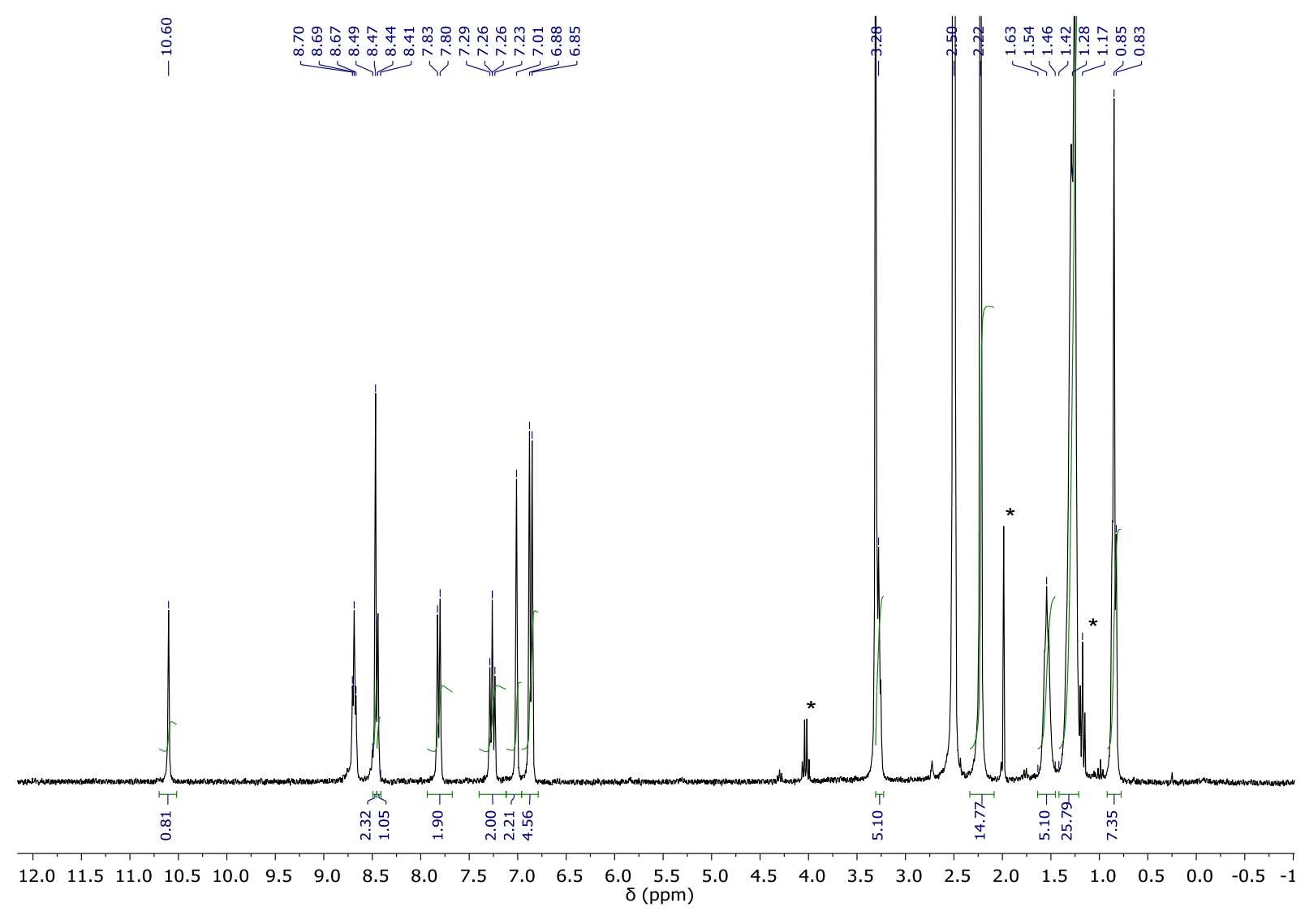

$31 \mathrm{P}\left\{{ }^{1} \mathrm{H}\right\}$ NMR (DMSO-d 6$)$

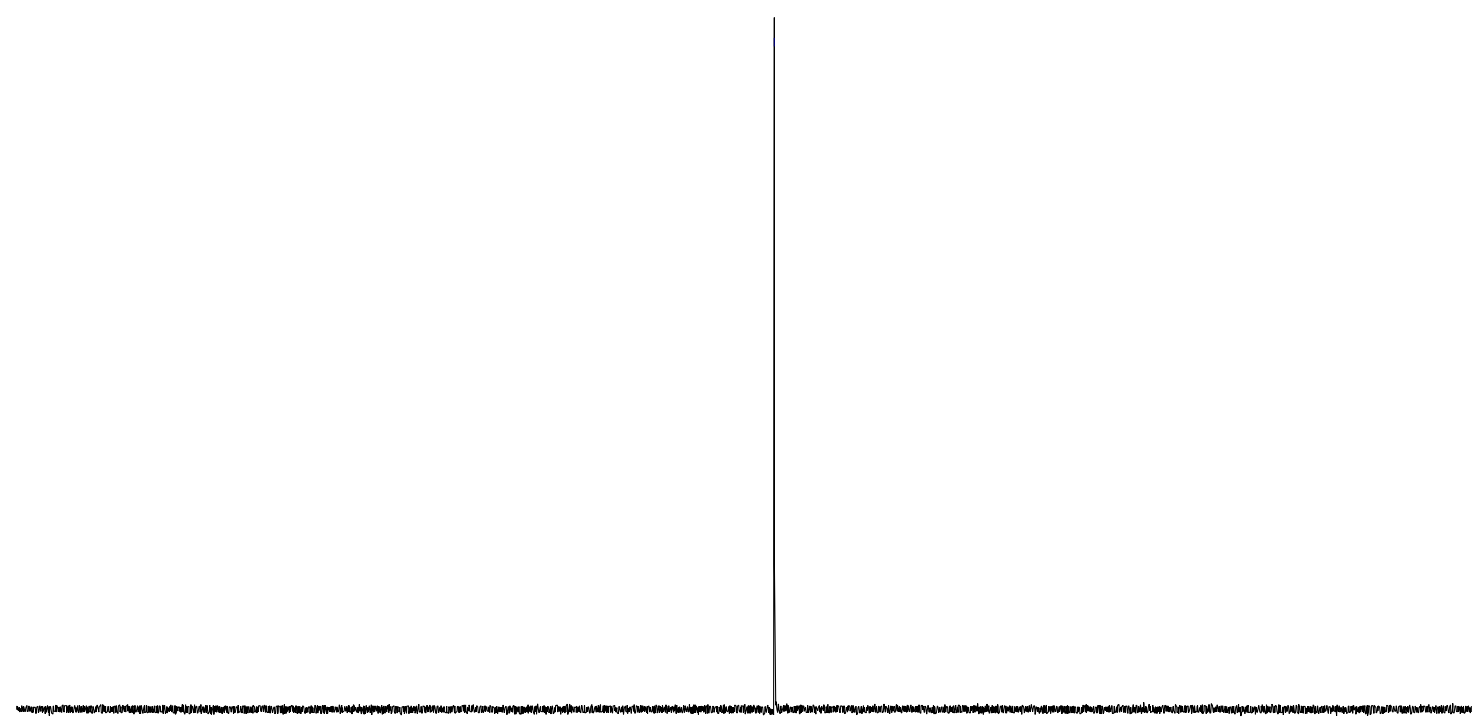

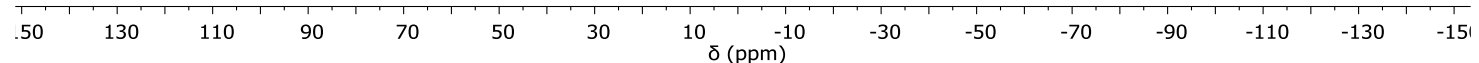


${ }^{13} \mathrm{C}\left\{{ }^{1} \mathrm{H}\right\}$ NMR (DMSO-d 6 )

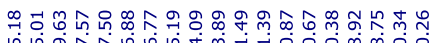

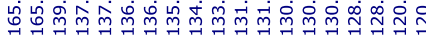

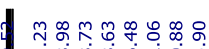

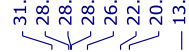

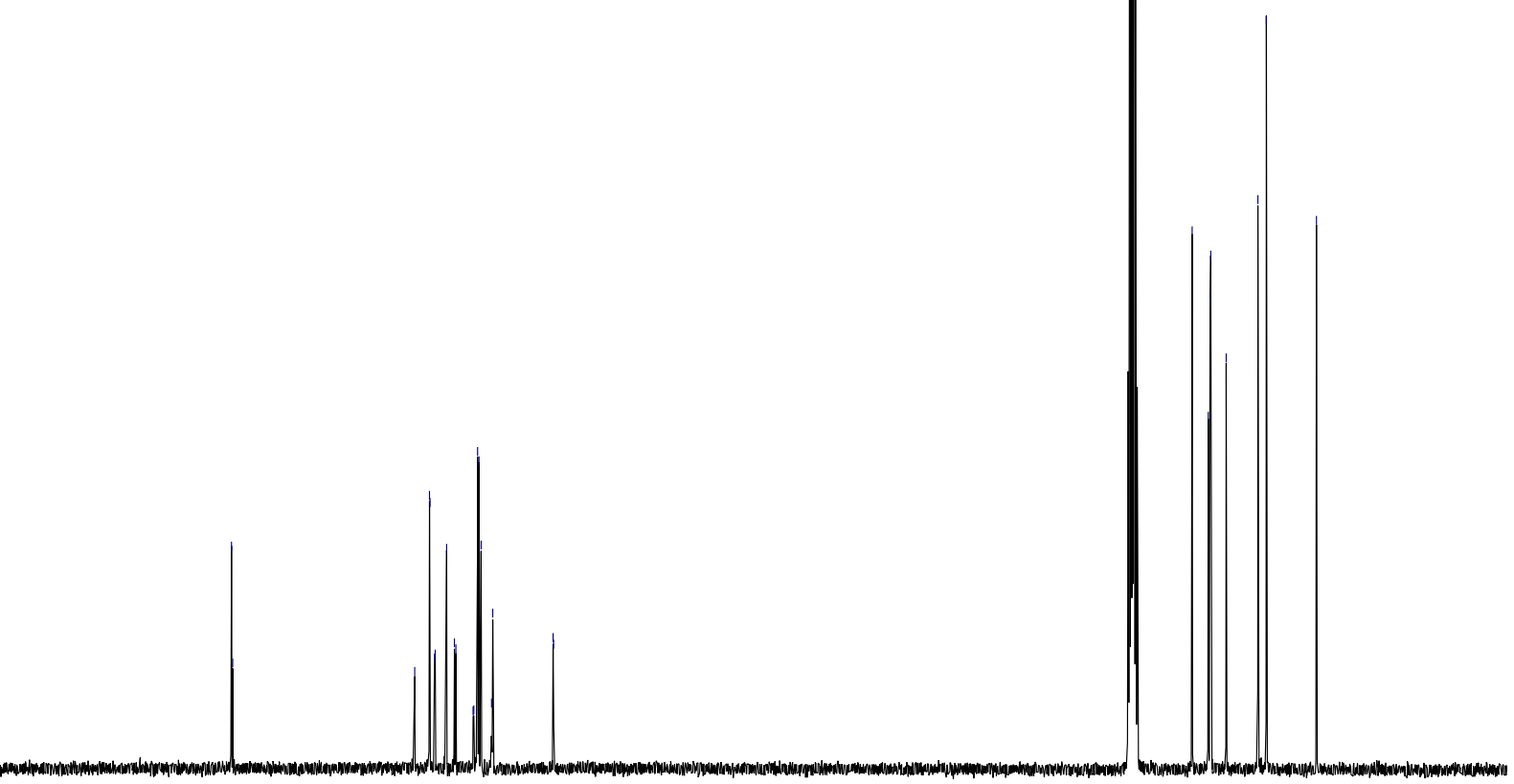

$\begin{array}{lllllllllllllllllllll}190 & 180 & 170 & 160 & 150 & 140 & 130 & 120 & 110 & \underset{\delta(\mathrm{ppm})}{100} & 80 & 70 & 60 & 50 & 40 & 30 & 20 & 10 & 0 & -10\end{array}$ 


\section{References}

(1) Zimbron, J. M.; Caumes, X.; Li, Y.; Thomas, C. M.; Raynal, M.; Bouteiller, L. Angew. Chem. Int. Ed. 2017, 56, 14016.

(2) a) Scerba, M. T.; DeBlase, A. F.; Bloom, S.; Dudding, T.; Johnson, M. A.; Lectka, T. J Phys Chem A 2012, 116, 3556; b) Desmarchelier, A.; Raynal, M.; Brocorens, P.; Vanthuyne, N.; Bouteiller, L. Chem Commun 2015, 51, 7397 ; c) Desmarchelier, A.; Alvarenga, B. G.; Caumes, X.; Dubreucq, L.; Troufflard, C.; Tessier, M.; Vanthuyne, N.; Ide, J.; Maistriaux, T.; Beljonne, D.; Brocorens, P.; Lazzaroni, R.; Raynal, M.; Bouteiller, L. Soft Matter 2016, 12, 7824; d) Caumes, X.; Baldi, A.; Gontard, G.; Brocorens, P.; Lazzaroni, R.; Vanthuyne, N.; Troufflard, C.; Raynal, M.; Bouteiller, L. Chem. Commun. 2016, 52, 13369.

(3) Kulkarni, C.; Meijer, E. W.; Palmans, A. R. A. Acc. Chem. Res., 2017, 50, 1928.

(4) Lortie, F.; Boileau, S.; Bouteiller, L.; Chassenieux, C.; Deme, B.; Ducouret, G.; Jalabert, M.; Laupretre, F.; Terech, P. Langmuir 2002, 18, 7218.

(5) Uray, G.; Stampfer, W.; Fabian, W. M. F. J Chromatogr A 2003, 992, 151.

(6) Roosma, J.; Mes, T.; Leclere, P.; Palmans, A. R. A.; Meijer, E. W. J. Am. Chem. Soc. 2008, 130, 1120. 